\title{
EVOLUTIONARY STUDIES ON MANIOLA JURTINA: THE ENGLISH MAINLAND, 1956-57
}

\author{
E. R. CREED \\ Genetics Laboratory, Department of Zoology, Oxford \\ W. H. DOWDESWELL \\ Biology Department, Winchester College \\ E. B. FORD and K. G. McWHIRTER \\ Genetics Laboratory, Department of Zoology, Oxford
}

Received 1.xi. 58

\section{DEVELOPMENTS IN THE AREA OF THE SOUTH ENGLISH STABILISATION}

IN the years 1950-52 Dowdeswell and Ford (1952, I953) found that throughout a large part of Southern England the females of Maniola jurtina, the Meadow Brown Butterfly, were so stabilised that all populations showed a characteristic spot-distribution with a large mode at o spots. The area in question stretched from the east coast (Ipswich), westwards to the Devon-Cornwall border, where there occurred a change within some twelve miles to another stabilisation in which the female spot-distribution is bimodal with a large mode at o spots and a lesser mode at 2 spots (defined as the East Cornish stabilisation). In their I953 paper, however, they noted that at Tiverton (I95I) in the extreme west of the South English stabilisation area, the female distribution showed a reduction of the steepness of the mode at o spots. The sample obtained at Taunton, Somerset, in 1952, had a similar tendency. With the small number of samples then available, however, these slight divergences did not much disturb the extreme and remarkable homogeneity of South English populations up to the region of the Cornish border.

By 1955 two other stabilisation areas, apart from those of South England and East Cornwall had been discovered, one in Penwith (in west Cornwall) and the other in the large islands of the Scilly group.

Sampling in the South English area was resumed in 1956 and it immediately became clear that the old stabilisation had broken up ; most populations showed greatly increased spotting in both males and females, and the mode at o spots in the female distributions was reduced and even sometimes accompanied by a secondary mode at 2 spots-a condition which up to $195^{2}$ had only been observed in east Cornwall and a few adjacent parts of Devon.

(i) Definitions of the South English spot-distributions

For convenience we have named the three types of spot-distribution found in the females in $195^{6}$ and 1957 as follows :

(i) Old English (O.E.) : the females maintain a pattern such that the specimens at o spots are 60 per cent. or more of the total 
of specimens at o, I and 2 spots, and the spccimens at 2 spots do not exceed the number of those at i spot.

(ii) New English (N.E.) : the females show a pattern in which the specimens at o spots are less than 6 o per cent. of the total at $\mathrm{o}, \mathrm{I}$ and 2 spots; the specimens at 2 spots do not exceed the total of those at I spot.

(iii) Pseudo-Cornish (P.C.) : the females show a pattern in which there is a major mode at o spots and a minor mode at 2 spots.

No attempt will be made here to deal in detail with the male spot-distributions. It may be briefly said that males with spotnumbers in excess of 2 were generally much more common than those with spot-numbers less than 2, and that some correlation with the three grades of female spot-frequency could be seen.

\section{(ii) Features of the South English data of 1956 and 1957}

All the data for these years are reproduced in the appendices I to 4 . Three main trends can be observed in them :

(i) 1956 seems to have marked the peak of a wave of high-spotting which occurred simultaneously nearly everywhere in the former South English stabilisation area. The populations in that year were very large. In 1957, after an abnormally mild winter and a prolonged spring drought, the species was much rarer ; the wave of high-spotting receded, except in the south-western counties of Devon, Somerset and Dorset.

(ii) In contrast to the situation in $195^{0-52}$, there were marked differences in the spot-distributions from place to place in 1956 and I957. In both these years, however, a strong stabilisation of " New English" populations was found in the south-western part of the area, in the counties of Devon, Somerset and Dorset. This fortunate event has cnabled us to study the transition from unimodal to East Cornish bimodal distributions in great detail (see below, pp. 37 I-82). Figs. I and 2 show by means of triangular graphs the rclationships of the South English samples in the two years.

(iii) A ncw and most remarkable feature of the post-1952 South English collections has been intra-seasonal heterogeneity. We are indebted to J. D. F. Frazer for pointing this out. He collected $M$. jurtina in the I955, I956 and 1957 seasons at Burham Down, Kent. (His I955 collection is the only one known to us to have been taken on the mainland in that ycar.) Thesc samples show a clear pattern in which both males and females have high spot-averages at the beginning of the cmergence, but suddenly change to lower spot-averages towards the middle of the cmergence. Frazer kindly sent a copy of his data to us late in the summer of $195^{6}$. In 1957 and $195^{8}$ we obtained samples 
throughout the emergence at a number of localities and certain of these confirmed the Burham Down observations.

During the period of stability in $1950-52$ we had obtained samples at various stages of the emergence at different localities and this had not, it seemed, in any way upset the general pattern of marked homogeneity. It occurred to us that the intra-seasonal shift, first observed by Frazer, was associated with changes in stabilisation and might indeed be one of the means by which such changes came about. This was confirmed by two opposing sets of data :

(a) Sampling of the Middleton (East) population throughout the 1957 emergence showed us that no intra-seasonal shift occurred there (see appendix 3). This locality is one of the two where no departure from the "Old English" stabilisation has been observed.

(b) Data from extensive samples of the Ipswich population, which were kindly sent to us by S. Beaufoy, show that the early emergence in 1956 was of a rather high-spotted N.E. type ; in 1957 the early emergence was similar, but was known to be succeeded by an O.E.-type later emergence; in $195^{8}$ the whole emergence was homogeneous and conformed to the N.E. type.

In selectional terms the intra-seasonal shift suggests that in some populations an ecological factor which normally operates adversely against the high-spotted specimens was lifted simultaneously over large parts of South England during such a time of year as to disturb the balance only of the first half of the emergence ; genes for high spotting might then be perpetuated in larger numbers than usual and would then have the opportunity in some cases to percolate through all or most of the emergence next year. This seems to have happened at Ipswich, eventually producing a population stabilised on the N.E. level instead of the O.E. level observed in $195^{0-52}$. In other cases, the move towards high-spotting seems to have been unsuccessful and may have been limited to the early part of the emergence before finally disappearing. (Appendices 2 and 4 contain the data relevant to the intra-seasonal shift.)

All data given in this series of papers are the result of estimates made by at least two of the authors according to the system described in Dowdeswell and Ford (1953) ; it would therefore be improper to make direct comparisons between data resulting from scoring by another worker and our data, since slight differences in convention might occur and upset the accuracy of the estimate. We have for this reason listed Frazer's data separately, which he kindly permits us to reproduce, though it is clear that comparisons made between his estimate of spotting in the early and in the later parts of the emergence are perfectly valid. 
(iii) Geographical patterns in the former South English stabilisation area, 1956-57

If the former South English stabilisation area is broken up into three sub-areas, (i) the south-western counties, that is, Devon, Somerset and Dorset, (ii) the south-eastern counties, that is, Hampshire, Sussex and Kent and (iii) counties lying north of the line joining the Severn and Thames estuaries, we find that populations in the south-western sub-area, with very few exceptions, have been stabilised on the New

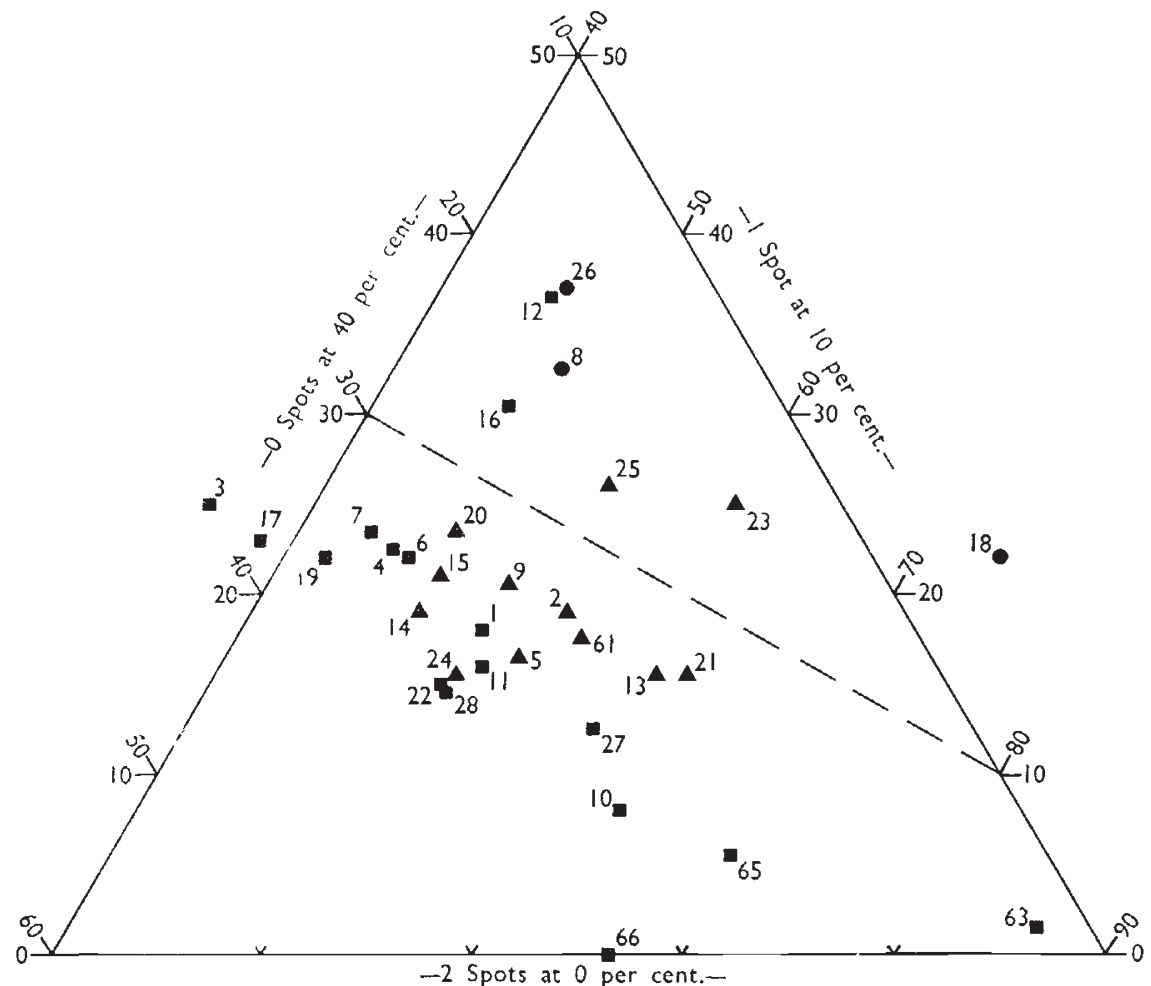

Fig. 1.-Maniola jurtina: English mainland and peripheral populations-female spotdistributions 1956. The frequency of $\mathrm{O}, \mathrm{I}$ and 2 spots are expressed as percentages of the total of these three values, the tail being disregarded. Entries above the broken linc refer to bimodal samples. The numbers correspond to placcs listed in appendices 1 to 3 and table 1 . - "East Cornish" populations; $\mathbf{A}$ - the south-western sub-area, including Lundy Island; - -the remainder of southern England and its periphery.

English distribution since $195^{6}$, and that populations in the southeastern sub-area showed slight differences in 1956, though not in I957, from those of the more northerly countics.

In figs. I and 2, the south-western samples are represented by triangles to distinguish them from the rest of the former South English stabilisation area. The numbers following the places mentioned below refer to entries in thesc figs.

I956, O.E. populations included Middlcton East (Iо) and, marginally, Woolbury Ring (27) in Hampshire, Sherbornc (2I) in Dorset and Newton Abbot (13) in Devon. 
I956, N.E. populations included Middleton West (I I), Worthy Down (28), Canterbury (I) and Shoreham (22) in the south-east sub-area; these four maintained modes at o spots between $5^{\circ}$ per cent. and 6o per cent. and reference to fig. I will show that they are somewhat distinct from the samples obtained in the more northerly sub-area, which includes Chelmsford (3), Holt (6), Ipswich (7), Rugby (I9), Cothill (4) and perhaps the small sample from Oxford,

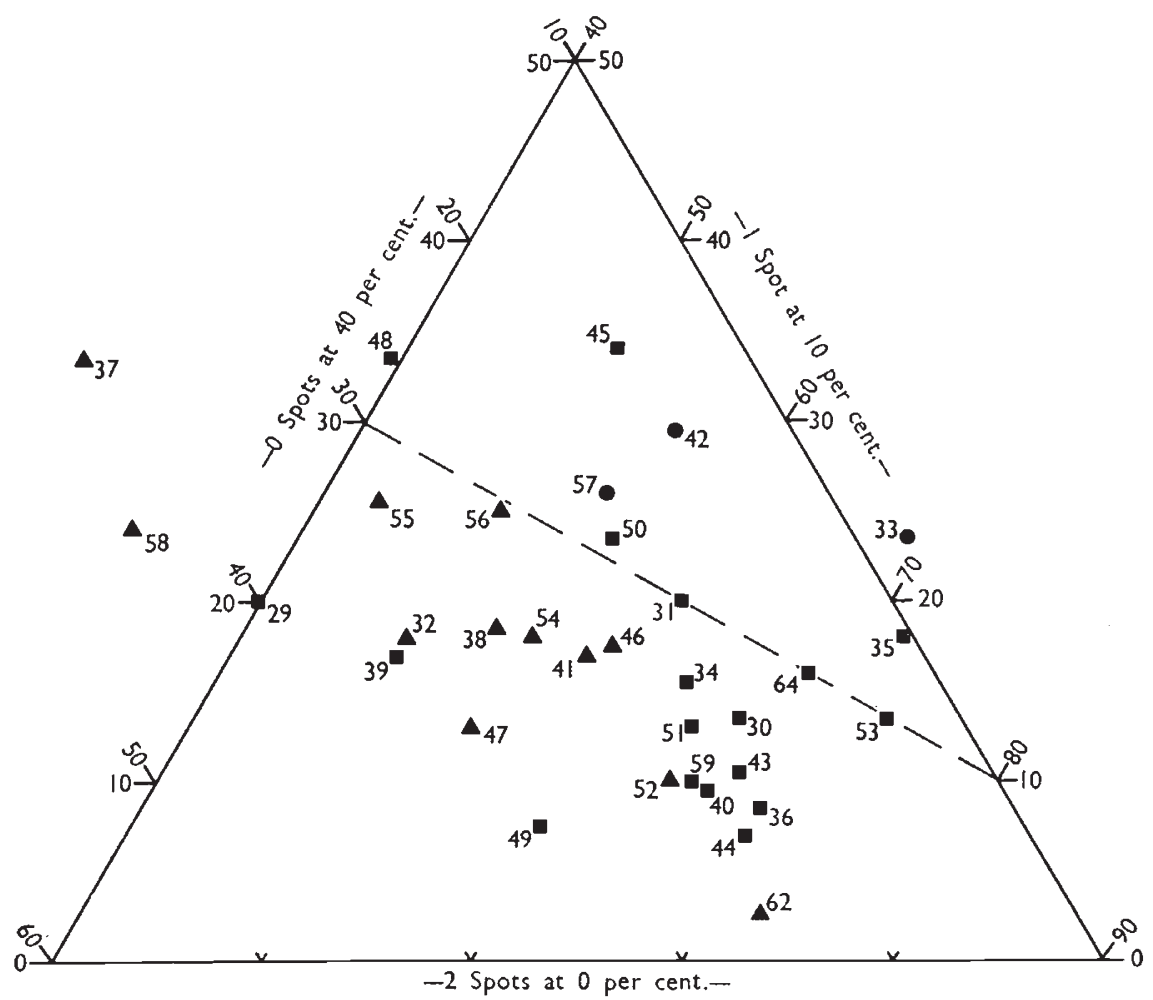

Frg. 2.-Maniola jurtina : English mainland and peripheral populations-female spotdistributions 1957. For explanation see fig. 1 on page 366 .

Parks (I 7). The south-western sub-area was strongly stabilised, as reference to fig. I will show.

i956, P.C. populations included Oxford, Medley Manor (i6), Tiverton (25), Taunton (23) and perhaps Newbury (I2), where our sample was very small.

I957, O.E. populations included all localities in the south-eastern and northerly sub-areas, though Ipswich (39 and 40), Oxford, Medley Manor (48 and 49) and Oxford, Parks (5O and $5 \mathrm{I}$ ) only showed this distribution in the second phases of their emergences. One exceptional south-western locality, Pilistreet (52) near the border of the East Cornish stabilisation, also showed the O.E. distribution (see p. 380 ).

I $957, \mathcal{N} . E$. populations included all south-western localities except Pilistreet (52); also the first phase of the Ipswich emergence (39). 
The two outstanding western populations Newton Abbot (47) and Sherborne (54) moved over from O.E. to N.E. against the general trend.

I957, P.C. populations included Newbury (45) and the first phases of the two Oxford samples ( $4^{8}$ and $5^{0}$ ). Hoylake (35), with a large

TABLE I

Spot-distributions of $\mathrm{M}$. jurtina populations in areas peripheral to the former South English stabilisation area

\begin{tabular}{|c|c|c|c|c|c|c|c|c|c|c|}
\hline \multirow{2}{*}{\multicolumn{2}{|c|}{ Locality }} & \multirow{2}{*}{ Year } & & \multicolumn{6}{|c|}{ Spots } & \multirow{2}{*}{ Total } \\
\hline & & & & 0 & I & 2 & 3 & 4 & 5 & \\
\hline - Lundy Island & . & 1955 & $\begin{array}{l}0 \\
\stackrel{0}{+}\end{array}$ & $\begin{array}{r}5 \\
47\end{array}$ & $\begin{array}{r}5 \\
18\end{array}$ & $\begin{array}{r}34 \\
5\end{array}$ & $\begin{array}{c}2 \\
\ldots\end{array}$ & $\begin{array}{l}\cdots \\
\cdots\end{array}$ & $\cdots$ & $\begin{array}{l}4^{6} \\
70\end{array}$ \\
\hline 6r. ", " & . & $195^{6}$ & $\begin{array}{l}0 \\
0 \\
+\end{array}$ & $\begin{array}{r}3 \\
45\end{array}$ & $\begin{array}{r}7 \\
21\end{array}$ & $\begin{array}{l}62 \\
14\end{array}$ & $\begin{array}{r}24 \\
4\end{array}$ & $\begin{array}{l}\mathrm{I} \\
\ldots\end{array}$ & $\begin{array}{l}\cdots \\
\cdots\end{array}$ & $\begin{array}{l}97 \\
84\end{array}$ \\
\hline 62. " " " & . & 1957 & $\begin{array}{l}\text { ô } \\
\text { o }\end{array}$ & $\begin{array}{r}\text { I } \\
29\end{array}$ & $\begin{aligned} \text { I } \\
\text { IO }\end{aligned}$ & $\begin{array}{r}\mathrm{I} 4 \\
\mathrm{I}\end{array}$ & $\begin{array}{l}3 \\
\ldots\end{array}$ & $\begin{array}{l}\cdots \\
\cdots\end{array}$ & $\begin{array}{l}\cdots \\
\cdots\end{array}$ & $\begin{array}{l}19 \\
40\end{array}$ \\
\hline 63. Isle of Man & . & $195^{6}$ & $\begin{array}{l}0 \\
0 \\
0\end{array}$ & $\begin{array}{r}7 \\
102\end{array}$ & $\begin{array}{l}22 \\
15\end{array}$ & $\begin{array}{r}85 \\
2\end{array}$ & $\begin{array}{l}13 \\
\cdots\end{array}$ & $\cdots$ & $\begin{array}{r}\mathrm{I} \\
\ldots\end{array}$ & $\begin{array}{l}128 \\
119\end{array}$ \\
\hline $\begin{array}{c}\text { 64. Pont-l'Evêque, } \\
\text { Normandy }\end{array}$ & & 1957 & $\begin{array}{l}0 \\
0 \\
0\end{array}$ & $\begin{array}{r}\mathbf{I} \\
47\end{array}$ & $\begin{array}{r}\text { I } \\
\text { I I }\end{array}$ & $\begin{array}{l}27 \\
\text { II }\end{array}$ & $\begin{array}{r}10 \\
3\end{array}$ & $\cdots$ & $\cdots$ & $\begin{array}{l}39 \\
72\end{array}$ \\
\hline 65. Sutherland & . & $195^{6}$ & $\begin{array}{l}\text { o } \\
0 \\
0\end{array}$ & $\begin{array}{r}8 \\
73\end{array}$ & $\begin{array}{l}27 \\
26\end{array}$ & $\begin{array}{r}101 \\
6\end{array}$ & $\begin{array}{r}19 \\
2\end{array}$ & $\begin{array}{c}6 \\
\ldots\end{array}$ & $\cdots$ & $\begin{array}{l}161 \\
107\end{array}$ \\
\hline $\begin{array}{l}\text { 66. Sutherland } \\
\text { (area "D ") }\end{array}$ & . & I956 & $\begin{array}{l}0 \\
\text { o } \\
+\end{array}$ & $\begin{array}{r}2 \\
10\end{array}$ & $\begin{array}{r}18 \\
5\end{array}$ & $\begin{array}{l}33 \\
\cdots\end{array}$ & $\begin{array}{c}2 \\
\ldots\end{array}$ & $\begin{array}{l}\cdots \\
\cdots\end{array}$ & $\begin{array}{l}\cdots \\
\cdots\end{array}$ & $\begin{array}{l}55 \\
\mathbf{1} 5\end{array}$ \\
\hline
\end{tabular}

The serial numbers in the left-hand column refer to the corresponding entry in figs. I and 2 .

mode at o and a small, possibly not significant, mode at 2 spots, seems aberrant.

\section{(iv) Long-term behaviour of stabilisations}

It should not be thought that the events described in Southern England are unique. Although so far as our information goes the East Cornish and West Cornish (Penwith) stabilisations seem to have remained unaltered from $195^{2}$ to $195^{8}$, the fourth stabilisation known to us, that of the large islands of Scilly, after being in force from at least 1950 to 1955, began to break up in the direction of lower spotting in I $95^{6}$ and had been partly restored by 1958. As in South England, one area (the largest of the islands), rcmained undisturbed throughout. Details of these events will be communicated in a paper devoted to the Isles of Scilly ; an account of the large island stabilisation up to 1955 is given in Dowdeswell, Ford and McWhirter (1957). 


\section{(v) Populations in areas peripheral to the former South English stabilisation area}

We have information on the condition of $M$. jurtina in the following areas :-Lundy, r 955-57; Isle of Man, r956; Sutherland, Scotland, r956; Pont-l'Evêque, Normandy, r957. The data are listed in table $\mathrm{r}$.

The Sutherland samples are fully discussed in Forman, Ford and McWhirter (r959). It will be noticed that the Lundy Island population tends to conform not with the south-western region (Devon, Somerset and Dorset), as might be expected from its geographical position, but with the more remote parts of Southern England. The Manx sample maintains its strong deviation towards very low spotvalues in both sexes which has been observed since r $95 \mathrm{r}$. Our first sample from Normandy seems to conform generally to the South English stabilization.

\section{THE WEST DEVON AND CORNWALL AREA}

\section{(i) Survey of previous results *}

By the end of the $195 \mathrm{I}$ season it had become clear that spotting in the females of Maniola jurtina was stabilised throughout the South of England with frequencies descending from a single mode at o spots. This pattern of frequency-distribution will be referred to as the "Southern English stabilisation". As already explained, however, minor variants can be recognised within it (the Old English and the New English forms, with more and less pronounced modes respectively). This general type of unimodal spotting distinguished all the populations studied from the North Sea to east Devon, though they are subject to great environmental differences, of climate, soil and vegetation.

As a result of work in previous years, it had already been realised that, widespread as it is, the Southern English stabilisation breaks down to other and characteristic values in some parts at least of Cornwall (Falmouth in the south and Hayle in the north). It was therefore decided to explore the situation from east Devon westwards in $195^{2}$.

Collecting was extremely hampered by wet weather, following long-continued heat and drought which had brought out the species unusually early, before we ourselves could be in the field. Five samples from central and west Devon were obtained. Threc were caught in the middle of the county, respectively at Okehampton, Lydford and Holsworthy. The others werc taken near the south coast, at Newton Abbot (mid-Devon) and at Noss Mayo (five milcs east of Plymouth). In all of them, the females were unimodal at o spots as in the rest of England eastwards, and the five populations

* The individual data upon which the results referred to in this sub-section are based can be obtained from Dowdeswell and Ford, I953. 
were homogeneous with one another $\left(\chi_{(4)}^{2}=5.39\right.$, with $P$ between 0.3 and 0.2 ).

It should here be mentioned that in $195 \mathrm{I}$ an additional sample (not published in our I953 paper) was obtained only a mile or so from Plymouth, though still to the east, in the Plymstock area (see table 2). The females are very homogeneous when compared with the samples obtained the following year in the above five Devon localities $\left(\chi_{(2)}^{2}=0.362\right.$, with $P=0.9$ to $\left.0 \cdot 8\right)$. It will be noticed that the high mode at o (over 6o per cent.) is consistent with the Old English type. This is confirmed by the males, which have a large mode at 2 spots and, for what the figures are worth, approximately equal numbers above and below that value.

TABLE 2

Spot-distributions at Plymstock, $195 \mathrm{I}$

\begin{tabular}{|c|c|c|c|c|c|c|}
\hline & \multicolumn{5}{|c|}{ Spots } & \multirow{2}{*}{ Total } \\
\hline & 0 & I & 2 & 3 & 4 & \\
\hline Females & 34 & 14 & 4 & 2 & $\cdots$ & 54 \\
\hline Males & I & 3 & 19 & 2 & I & 26 \\
\hline
\end{tabular}

Proceeding farther west, to the neighbourhood of the DevonCornwall border and east Cornwall, samples from another group of five localities (Plymouth North, Plymouth Roborough, Tavistock, Lewannick and Lanivet) were obtained in 1952. Here we pass to a situation of a different kind, in which the females are bimodal with a greater mode at $o$ spots and a lesser at 2. These five populations also proved homogeneous with one another $\left(\chi_{\left({ }_{12}\right)}^{2}=8 \cdot 778\right.$, with $P=0.0 \cdot 8 \cdot 7)$, in spite of considerable differences in habitat: coastal, inland and a locality (Lanivet) separated from the rest by the granite intrusion of Bodmin Moor. The difference between this group and the one just referred to from Devon is immensely significant $\left.\left(\chi_{(3)}^{2}\right)=4 \mathrm{I} \cdot 4^{8} \mathrm{I}\right)$. When the 195 I Plymstock sample is included, the distinction is increased to $\chi_{(3)}^{2}=50 \cdot 978$.

After the 1952 season we were, then, faccd with the following situation. A stability, characterised by female spotting unimodal at o spots, persisted from the coast of the North Sea across Southern England to west Devon. Near the Cornish border, and for a considerable distance beyond, this is replaced by a bimodal spot-distribution, also homogeneous. That area was sampled well inland (Lewannick), half-way thence to the south coast (Tavistock), at two places near Plymouth, and thirty miles westwards (Lanivet).

Although we are not in this account concerned with the situation in west Cornwall, it is desirable for completeness to mention that Maniola jurtina becomes rare or absent in the country immediatcly 
east of the Hayle-Marazion isthmus, isolating an entirely distinct and apparently stabilised type on the Land's End peninsula ; one in which the females are unimodal at 2 spots like the males, only with the mode less pronounced. Two somewhat exceptional populations are left on either side of this stretch of isolating territory; in the Falmouth district to the south and on the Hayle sandhills, in wholly abnormal conditions, to the north.

The whole situation here described is the one which Dobzhansky and Pavlovsky (I957) summarise in the following terms : "Populations of the butterfly Maniola jurtina are rather uniform throughout southern England, despite some obvious environmental diversity in different parts of this territory." In reality, the respective stabilisations persisted in the face of great environmental differences, while the chances (measured by $\chi_{\left({ }_{3}\right)}^{2}=4 \mathrm{I} \cdot 48 \mathrm{I}$ with $\left.P=5 \cdot \mathrm{I} 7 \times \mathrm{IO}^{-9}\right) *$ are almost I in 200 million that the distinction between the Devon (i.e. Southern English) and East Cornish stabilisations is fortuitous. The difference is even greater when the Plymstock sample, not previously described, is included (p. 37o). Considering this, and the other facts mentioned here, it seems that Dobzhansky and Pavlovsky's statement has not been based upon a sufficiently detailed examination of the published data.

\section{(ii) Results obtained in 1956}

Subsequently to $195^{2}$, work on Maniola jurtina in the Isles of Scilly prevented us for some years from returning to the study of this insect on the mainland. In 1956, however, we determined to examine the way in which the spot-distributions found respectively in Devon and east Cornwall change from one to the other.

As explained previously, we already knew that the difference between them is very great and that each is homogeneous over a wide and highly diversified area, coastal and inland. It was also clear that there was no tendency for the two types to approximate even in the localities we had examined where they approached most closely. In the inland sector, which was the one we selected for study (see map, fig. 3), these were twelve miles apart, at Lydford (Devon) and Lewannick (Cornwall). Provided that the diversity had persisted throughout the intervening four years, the problem was likely to be of much interest since it will be seen that at its longest the cline involved could be no more than twelve miles. Yet the facts prove more surprising than anything we had anticipated.

The work was conducted by K. G. McWhirter and E. B. Ford without W. H. Dowdeswell who, unfortunately, could not be present in I956. Our first task was to determine whether the Devon and East Cornwall populations previously studied still remained dissimilar. We therefore visited the large field (SX634992) which had provided the

* This extension of the $\chi^{2}$ table was kindly calculated for us by Mr N. T. J. Bailey.

$\dagger$ A combination of letters and numbers in brackets following a locality represents its position on the National Grid. 
Okehampton sample in $195^{2}$; also the Lydford locality ( $\mathrm{SX}_{48786}$ ) twelve miles farther west-south-west. The results are shown in tables 3 and 4 for the two sexes separately, where they are compared with the

\section{TABI.E 3}

The Devon and Cormish spot-distributions for 1.952 and 1956 compared in the Okehampton to Lereannick transil ; fermales

\begin{tabular}{|c|c|c|c|c|c|c|c|c|}
\hline \multirow{2}{*}{ Locality } & \multirow{2}{*}{ Year } & \multicolumn{6}{|c|}{ Spots } & \multirow{2}{*}{ Totals } \\
\hline & & 0 & I & 2 & 3 & 4 & 5 & \\
\hline $\begin{array}{c}\text { Okehampton, Devon } \\
, ",\end{array}$ & $\begin{array}{l}1952 \\
1956\end{array}$ & $\begin{array}{l}36 \\
45\end{array}$ & $\begin{array}{r}9 \\
29\end{array}$ & $\begin{array}{r}5 \\
20\end{array}$ & $\begin{array}{l}3 \\
5\end{array}$ & $\begin{array}{l}\ldots \\
\ldots\end{array}$ & $\ldots$ & $\begin{array}{l}53 \\
99\end{array}$ \\
\hline Lydford, Devon & 1952 & $2 \mathrm{I}$ & I 2 & 3 & $\ldots$ & $\ldots$ & $\cdots$ & 36 \\
\hline$" \quad$, & 1956 & 50 & 27 & 20 & I I & $\cdots$ & ... & 108 \\
\hline I.ewannick, Cornwall & 1952 & 28 & 17 & $2 \mathrm{I}$ & 7 & $\cdots$ & $\ldots$ & 73 \\
\hline$", \quad$, & $195^{6}$ & 44 & I 8 & $3^{\circ}$ & Io & 2 & $\cdots$ & 104 \\
\hline
\end{tabular}

I952 data when availablc. It is evident that the females are still clearly unimodal at o. This mode is, however, somewhat less accentuated, and to a significant degree. The difference between the years being

TABLE 4

The Devon and Cornish spot-distributions for 1956 (compared with 1.952 where available); males

\begin{tabular}{|c|c|c|c|c|c|c|c|c|}
\hline \multirow{2}{*}{ Locality } & \multirow{2}{*}{ Year } & \multicolumn{6}{|c|}{ Spots } & \multirow{2}{*}{ Totals } \\
\hline & & o & $I$ & 2 & 3 & 4 & 5 & \\
\hline Okehampton, Devon & 1952 & $\cdots$ & & I4 & 6 & 2 & $\ldots$ & 22 \\
\hline$\quad, \quad \quad "$ & I 956 & I & 8 & 55 & I 8 & I & $\cdots$ & 83 \\
\hline Lydford, Devion & 1956 & 4 & 8 & 49 & 15 & 5 & 2 & 83 \\
\hline Lcwannick, Cornwall & I952 & 2 & 2 & 25 & 4 & 2 & .. & 35 \\
\hline$"$ & $195^{6}$ & 2 & 8 & $5^{8}$ & 27 & 8 & I & 104 \\
\hline
\end{tabular}

measured by $\left.\chi_{(2)}^{2}\right) 7.004$ at Okehampton, and by $\chi_{(2)}^{2}=6.228$ at Lydford, both giving $P$ betwecn 0.05 and 0.02 . This indicates a shift from the Old Fnglish to the New English types within the typical Southern English female stabilisation : an adjustment which by $195^{6}$ had occurred widcly in the rest of Southern England eastwards. The females of the Okehampton and Lydford populations for that year are evidently homogencous (and see p. 375) when compared with one another, as they are when compared jointly with the nine "New 
English" spot-distributions found east of Devon in the same season * $\left(\chi_{(3)}^{2}==\right.$ I $\cdot 14$, with $P$ from $0 \cdot 8$ to $\left.0 \cdot 7\right)$.

In these nine "New English" populations, the females are extremely homogeneous with one another $\left(\chi_{(16)}^{2}=I I \cdot I 44\right)$. On the other hand, the males are heterogeneous $\left(\chi_{(16)}^{2}=30 \cdot 56\right)$ being, as usual in that sex, more prone to be independently adapted to the minor environmental distinctions of each locality. The male spot-distributions at Okehampton and Lydford (table 4) are, however, evidently homogencous in 1956 .

We next proceeded to reinvestigate the nearest district previously studied within the East Cornish stabilisation : that is to say, Lewannick. Here we found that we could no longer obtain samples in the two neighbouring localities where we collected in 1952. One was a large sloping meadow which had now been ploughed. The other was a narrow valley (SX 292797) in which the grass had become much invaded by bracken and brambles from the steep sides, so destroying the greater part of the insect's habitat.

We accordingly searched the Lewannick neighbourhood for another area where the butterfly was common. This we found just over threequarters of a mile eastwards, in the valley of the Inny near Drinnick where the river is crossed by Trekelland Bridge (SX 301797$)$. The sample obtained at this place showed a spot-distribution entirely distinct in character from that of the Okehampton and Lydford specimens, being of the East Cornish type (table 3) ; that is, bimodal in the female. In that sex it was closely homogeneous with the condition as established in the same district four years before $\left(\chi_{\iota_{3}}^{2}\right)=\mathrm{I} \cdot 0 \mathrm{~g}^{2}$, with $P=0.8$ to 0.7$)$, but it was only doubtfully so in the males $\left(\chi_{(\mathrm{r})}^{2}=3 \cdot 007\right.$, with $P=0 . \mathrm{I}$ to 0.05$)$.

Owing, as it proves, to the small size of the sample which it was possible to collect, it was in neither sex fully heterogeneous with the estimate for the combined Okehampton and Lydford populations, though it approached this in the females (for which the difference is measured by $\chi_{(3)}^{2}=6.867$, with $P=0.1$ to 0.05 ; while for the males, $\chi_{\left({ }_{3}\right)}^{2}=3 \cdot 575$, with $P$ nearly $\left.0 \cdot 3\right)$. It will be shown, however, that the "Lewannick" sample can be added to that from another East Cornish population with which it is homogeneous. The difference between the two combined, compared with the spot-distributions found in Devon, is heavily significant in the females though not in the males ( $p$. $376)$.

We therefore set out to analyse the transition betwcen the two types. This we did by sampling the $M$. jurtina population in the twelve miles which separate these localities. We decided first to subdivide the distance, which there includes the county boundary, into three blocks, working from north-east to south-west. We accordingly

* Shapwick (Somerset), Middleton West (Hampshire), Worthy Down (Hampshire), Shoreham (Sussex), Canterbury (Kent), Cothill (Berkshire), Rugby (Warwickshire), Ipswich (Suffolk), Holt (Norfolk). 
advanced approximately four miles from Lydford finding, with some difficulty, a suitable collecting ground in a valley at Chillaton $\left(\mathrm{SX}_{435^{81}} 8\right)$. Here, to our surprise, the population proved completely Southern English in both sexes (tables 5 and 6).

TABLE 5

Spol-distributions in the localities sampled between the known Southern English (Lydford) and East Cornish (Lewannick) slabilisations in 1956; females

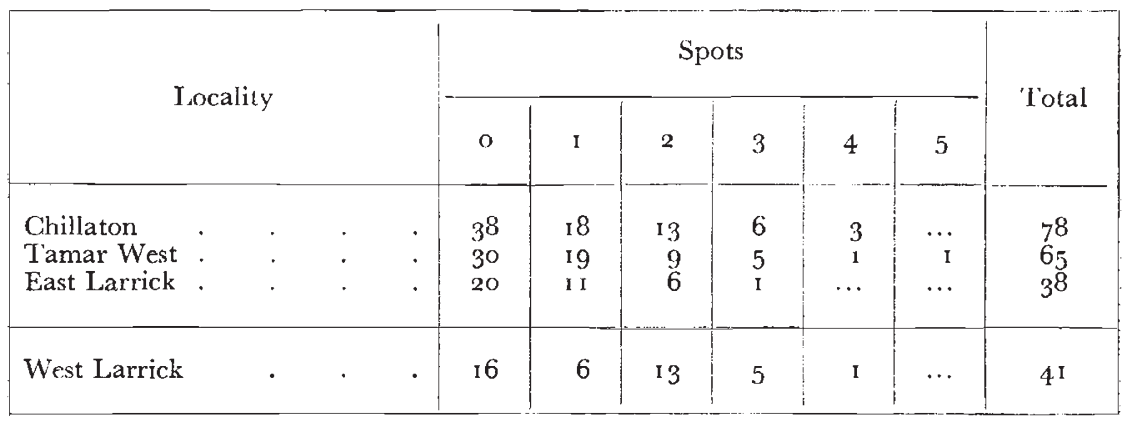

We next proceeded a further four and a half miles in the direction of the Lewannick area and discovered a locality near Hexworthy, in the Tamar valley on the west side of the river $\left(\mathrm{SX}_{3} 668\right.$ I I), where the butterfly was in some numbers. It was, however, not easily caught,

TABLE 6

Spot-distributions in the localities sampled between the known Southern English

(Lydford) and East Cornish (Lewannick) slabilisations in 1956; males

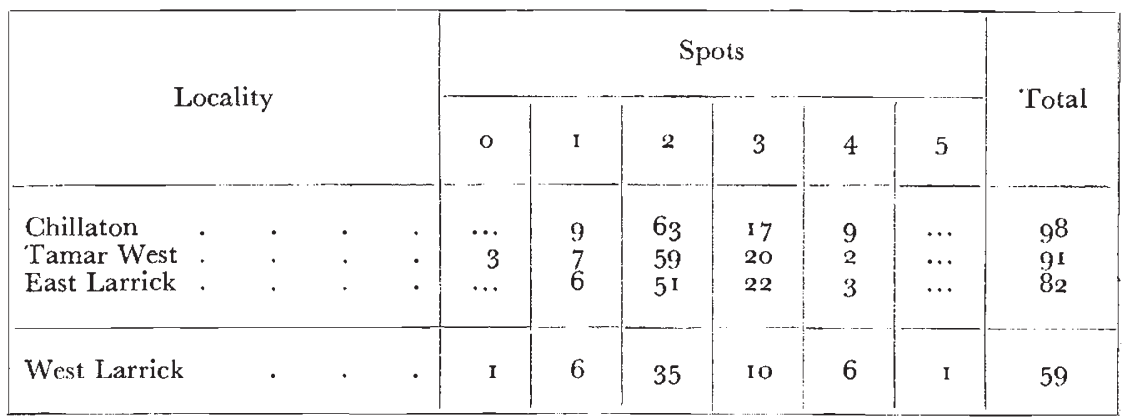

as the insects ranged widely at a rather low density over extensive ficlds. The resulting sample (tables 5 and 6) proved completely Southern English in spotting, without any indication that we were now within four milcs of the "Lewannick" locality at the Inny Bridge which, as we knew, falls within the East Cornish stabilisation.

The intervening country, though irregular, on the whole rises from the valley of the Tamar until within a quarter of a mile of the Inny it drops steeply down to that river. We decided to advance approximately half-way across this area to Larrick, where we found a suitable collecting ground in the valley of a stream which runs eastward from the heights above the Inny valley. This stream is (at 
$\mathrm{SX}_{329806)}$ crossed by the lane from Launceston to Trebullett. The position is approximately two and a quarter miles from the population (proved Southern English) on the west side of the Tamar valley, and one and three-quarter miles from that, proved East Cornish, on the banks of the Inny. From here we moved westwards collecting on the southern side of the stream, keeping an account of our results on the way.

By the time we had worked through two fields before crossing a lane at Larrick farm and three subsequently, we had accumulated 82 males and 38 females. We accordingly paused on the east side of the hedge between the third and fourth fields from the farm ( $\left.\mathrm{SX}_{322803}\right)$

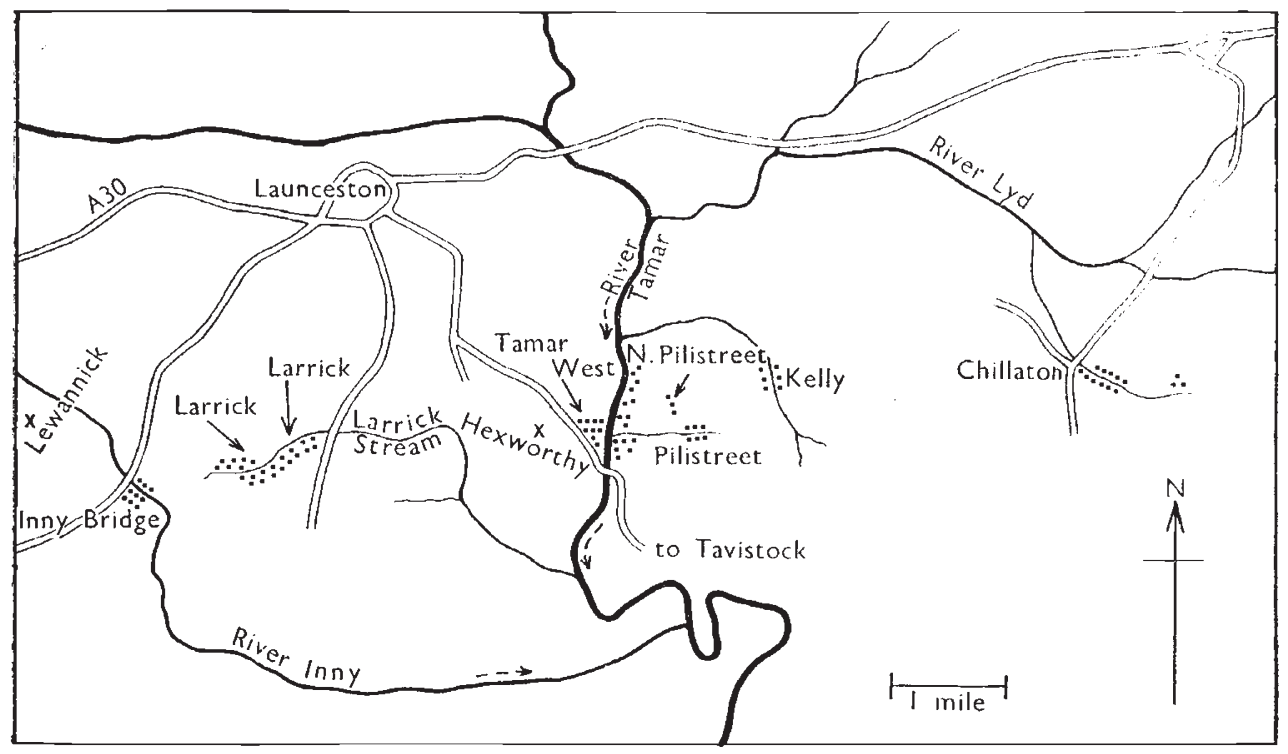

FIG. 3.-Map of the region in which we studied the transition from the Devon to the Cornish types of spotting in Maniola jurtina. The localities where the samples were obtained are indicated by dots. (The river Tamar is here the county boundary.)

and scored our sample (tables 5 and 6). Since we were making our way up the course of the stream, which ran beside us on our right, we describe this area as "East Larrick" (SX 322 to 328 and 803 to 807). The result was still completely Southern English, though we were now no more than a mile and a quarter from the East Cornish population by the Inny Bridge (Lewannick). Indeed the spotdistributions found in the whole series of localities from Okehampton to this point (Okehampton, Lydford, Chillaton, Tamar West and East Larrick) are extraordinarily homogeneous. Their uniformity is measured by $\chi_{(8)}^{2}=2.74 \mathrm{I}$ giving $P=0.95$ to 0.9 for the females, and by $\chi_{(8)}^{2}=3.662$ giving $P=0.9$ to 0.8 for the males.

We now climbed through the hedge and proceeded across the fourth field westwards from Larrick farm. It is of large size and the greater part is flat, but it slopes steeply down to the stream on its 
northern sidc. As we advanced, making a rough assessment of our capturcs on the way, we became aware that a change in spot-distribution had at last occurred. We proceeded to collect in the next ficld westwards and on some rough ground, interspersed with gorsc and bramble, separated from it by a narrow marshy copsc. This marsh continued the line of the stream which had, in fact, turned northwards just previously.

These two ficlds, and the picce of rough ground beyond them, we describe as the "West Iarrick" locality (SX 318322 and SX8oI803). Having accumulated 59 males and 4 I females there (tables 5 and 6), we sat down to score thcm. The result was spectacular, confirming the counts made while collecting. The femalcs wcre completely East Cornish in type, bimodal and highly homogeneous with the Lewannick sample by the river Inny $\left(\chi_{(8)}^{2}=0.5\right.$ I 2 , with $P=0.95^{-}$ $0 \cdot 90)$. They are heterogencous when compared with those from East Larrick in the ficlds immediately to the east $\left(\chi_{(2)}^{2}=:=7 \cdot 35^{\circ}\right.$, with $P=0 \cdot 05-0 \cdot 02)$.

When the females of the East Cornish stabilisation from Wcst Larrick and the Lewannick area (at the Inny Bridgc) arc combined, which their extreme homogeneity fully allows, they may be compared with the Southern English series from Okchampton to East Larrick, itself already shown remarkably uniform. The result further demonstrates the reality of the difference betwcen thesc two types of spot-distribution, for the heterogeneity between them is measured by $\chi_{(3)}^{2}=14.539$, giving $P=0.01-0.001$.

The males, on the other hand, are moderatcly homogeneous with the Southern English type at East Larrick $\left(\chi_{\left(_{3}\right)}^{2}=5.55^{\circ}\right.$, with $P=0 \cdot 2-0 \cdot I)$. They are fully so with those of the Lewannick (Inny Bridge) area $\left(\chi_{\left({ }_{3}\right)}^{2}=2 \cdot 008\right.$, with $\left.P=0 \cdot 7-0 \cdot 5\right)$. The males from West Larrick and Lewannick combined do not differ significantly from the Southern English series from Okchampton to East Larrick $\left(\chi_{\left({ }_{3}\right)}{ }^{\prime}\right)=5 \cdot 206$, with $\left.P=0 \cdot 2-0 \cdot I\right)$. As already explained, they do not thcrefore provide a clear criterion of the distinction between the East Cornish and main Southern English stabilisations.

When the female samples along the transect are compared, it is found that the difference between the Southern English and the East Cornish spot-distributions is greatest at the boundary between them. This is most conveniently shown when the average spot-numbers are considered. These are, of course, greater in the Cornish stabilisation, with its subsidiary mode at 2, than in the Southern English, with its single mode at o. The values may be plotted against the distance along the transect from a given datum point, in this case Lewannick (see fig. 4). It will then be scen that the spot-average for West Larrick is even higher than that for Lewannick, while that for East Larrick is even lower than that for Tamar West. "This is the precise opposite of the situation found in a cline. No comparable effect can be detected when the male spot-values are plotted in a similar manner. 
The evidence consequently indicates that the Southern English and East Cornish spot-distributions change abruptly from one to the other. This they do within a few yards; a transition which, in 1956 , occurred at the ordinary field-hedge between the West and East Larrick collecting areas $\left(\mathrm{SX}_{322803}\right)$. Yet this presents no barrier to the insects, which are constantly seen crossing it.

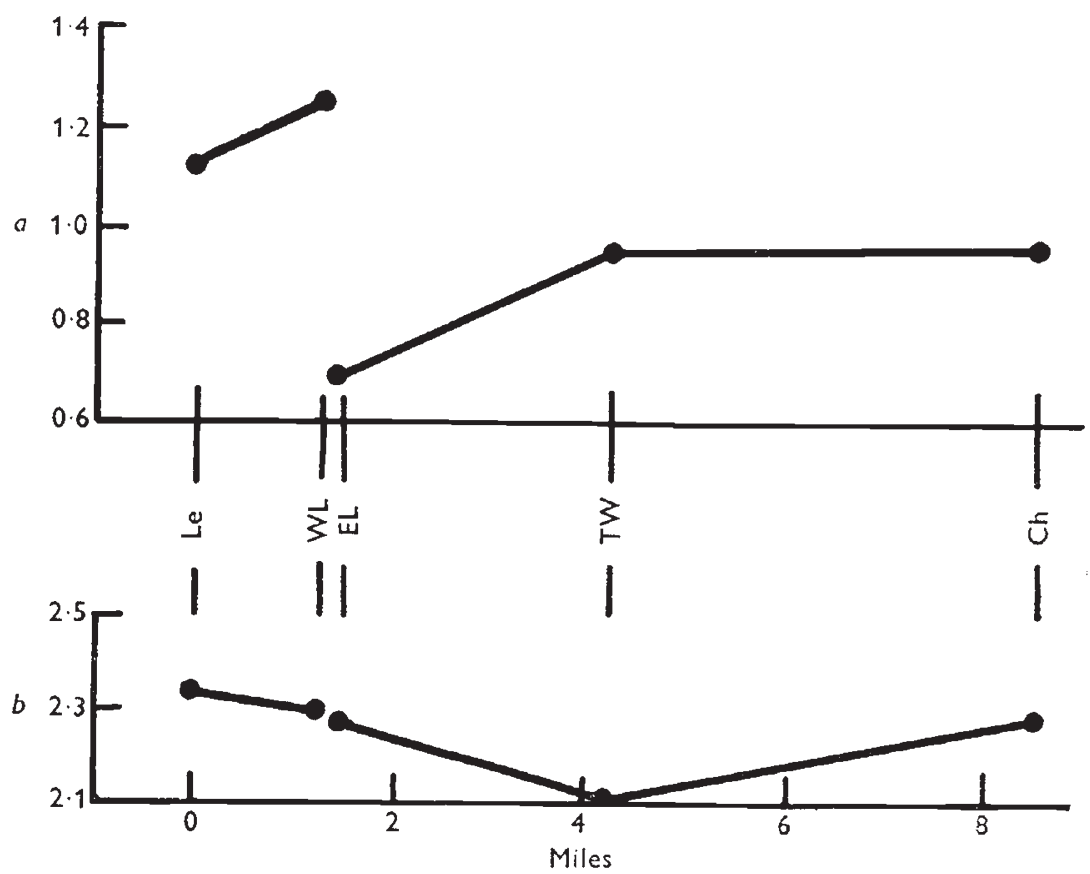

Fig. 4.-Maniola jurtina: the boundary between the East Cornish and Southern English stabilisations-1956. The average spot-numbers of $(a)$ the females and $(b)$ the males are plotted against the distance along the transect. For explanation see text page 37 6. (Le, Lewannick; WL, West Larrick; EL, East Larrick ; TW, Tamar West ; Ch, Chillaton.)

\section{(iii) Results obtained in 1957}

It was important to determine whether the abrupt discontinuity in spotting between the Southern English and East Cornish stabilisations, discovered in 1956 , persisted the following year. We therefore again studied the spot-distributions of Maniola jurtina in the critical area of the Devon-Cornwall border in 1957. The work was more difficult than in the prcvious season because the butterfly was on the whole considerably rarer, due, no doubt, to the abnormal weather conditions of the spring and early summer. An unprecedented period of drought had continued up to early July and was followed by much rain for the rest of that month.

W. H. Dowdeswell, who collaborated in initiating thcse studies, and has great experience of them, accompanied us this year. We were joined also by E. R. Creed. 
Our first objective was to collect in the Lewannick area at Inny Bridge, where we captured I 26 malcs and I 55 females (see tables 7 and 8 ). The two sexes were respectively homogeneous when compared with the samples obtained the previous year, the females being

TABLE 7

Spot-distributions in the localities sampled in the $8 \frac{1}{4}$ miles from Chillaton (Deion) to Lewannick (Cornwall) in 1957 ; females.

The localities are arranged from east to west

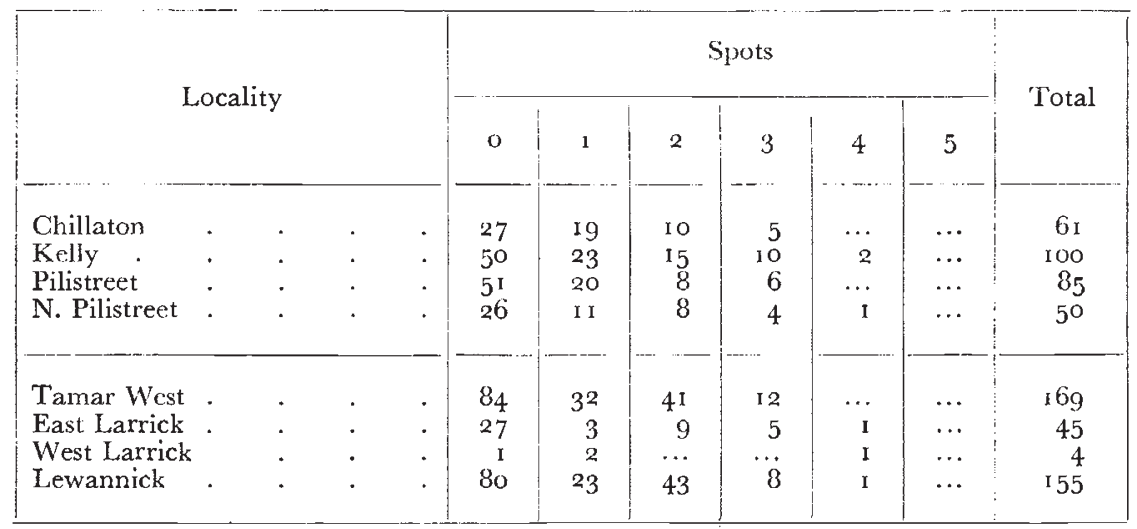

TABLE 8

Spot-distributions in the localities sampled in the $8 \frac{1}{4}$ miles from Chillaton (Devon) to Lewannick (Cornwall) in 1957 ; males.

The localities are arranged from east to west

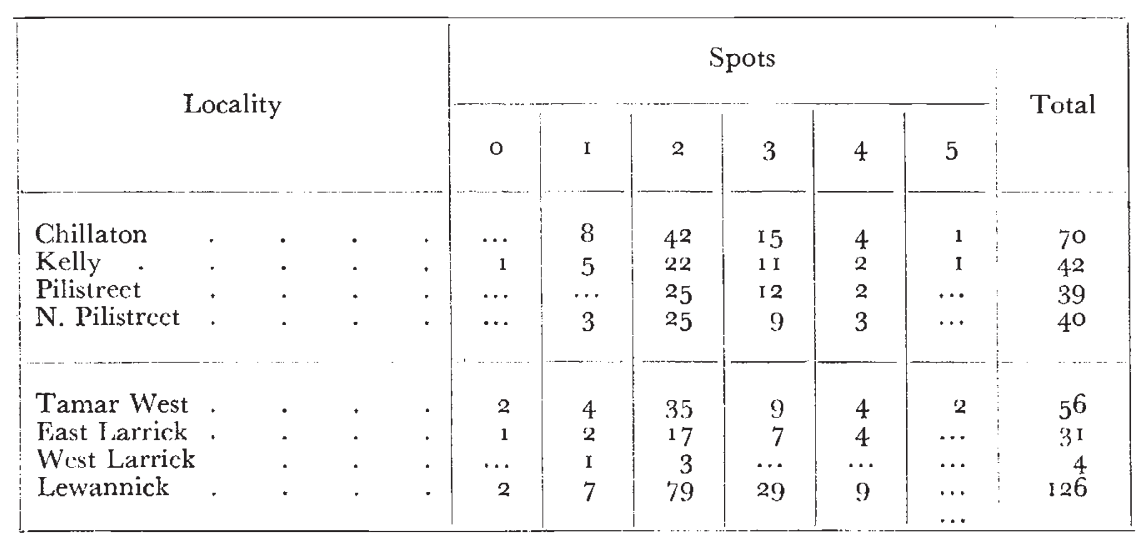

bimodal (in that sex the comparison is measured by $\chi_{1_{3}^{2}}^{2}=3 \cdot 9^{12}$, with $P=0.3$ to 0.2 ; whilc for the males $\chi_{(3)}^{2}=\mathrm{I} \cdot 250$, with $P=0.8$ to 0.7 ). It was cvident, therefore, that in 1957 the East Cornish type of spotting persisted unaltered in the Lewannick district.

We also collccted on the west side of the river Tamar, near Hcxworthy, in the locality studied in 1956 (p. 374). The butterflies were difficult to obtain, being widespread at a low density, so that it was necessary to spend two days there. However, wc were at length 
fortunate in discovering two fields in which considerable numbers were to be found in long grass. In all, we amassed 169 females and $5^{6}$ males (see tables 7 and 8). Here we had been within the normal Southern English stabilisation the previous year, so we were surprised to find the females were now bimodal and completely of the East Cornish type.

Between the two localities so far studied (Inny Bridge and the west side of the Tamar near Hexworthy) lay the critical Larrick area which previously included the abrupt transition in spotting. Here $M$. jurtina was much rarer owing to the parched condition of the fields. The West Larrick locality was practically denuded of butterflies and a long search resulted only in 4 females and 4 males (see tables 7 and 8). The East Larrick region, being moister, was less unfavourable and there we amassed 45 females and 3 I males (see tables 7 and 8) : a considerable number of these were caught in an orchard separated from the first field west of Larrick farm only by a stream narrow enough to jump over and a straggling hedge. It will be remembered that here in the previous year the females were of the normal Southern English type, being unimodal at o spots. They were now bimodal, the samples for ${ }_{9} 956$ and 1957 being heterogeneous $\left(\chi_{i_{2}}^{2}=7 \cdot 988\right.$, with $\left.\mathrm{P}<\cdot 02\right)$. This result accords with the similar situation two and a half miles farther cast on the Cornish bank of the Tamar, suggesting that we had to deal with a change affecting a tract of country rather than independent adjustments to individual localities.

The spot-distributions in these three places, Lewannick, East Larrick and the west side of the Tamar, proved to be homogeneous (for the females, $\chi_{(6)}^{2}=7.925$, with $P=0.3$ to 0.2 ; for the males, $\chi_{(6)}^{2}=3 \cdot 036$, with $P$ approximately $\left.0 \cdot 8\right)$. The 4 females and 4 males captured at West Larrick in 1957 are omitted from this calculation. Glearly it would not be right to include with East Larrick a sample too small to be judged independently, one from a population which had in fact been heterogeneous with it the previous year.

Thus the Cornish form of spotting evidently now affected the jurtina population as far east as the Tamar. It was necessary, therefore, at this stage to locate an unchanged English stabilisation as a preliminary to discovering whether or not the transition between the two types remained abrupt. Consequently we advanced four and a half miles to the next locality east of the Tamar where we had obtained information the previous year: that is to say, Chillaton. Here the Southern English stabilisation still persisted in 1957 (see table 7), the females being unimodal at o spots.

It was now clear that in the transect which we were studying, the change from the East Cornish to the Southern English spotting occurred somewhere between Chillaton and the Tamar; presupposing, that is to say, that the distinctive types were to be found uniformly up to some transition area, broad or narrow, rather than in an independent scatter of localities. Consequently we looked for a suitable collecting 
ground in this stretch of country. We found one in a valley at Kclly ( $\mathrm{SX}_{3} 888$ I3) $_{3}$ approximately two and three-quarter miles west of Chillaton. Here the jurtina population was still of the Southern English type, unimodal at o spots (see table 7), though we were now only one and a quarter miles east of the Tamar near Hexworthy.

At that point the river flows close to the eastern side of its floodplain. A single row of ficlds about 150 yards wide separates it from a steep wooded bank, about I 5 o fcet high, above which are open fields. We collected from the cdgc of these woods, at the top of the declivity, back for a few hundred yards, choosing the north side of a small valley near Pilistreet $\left(\mathrm{SX}_{375807}\right)$. The sample obtained therc was again completely Southern English, the females being unimodal at o spots. So too, was another (which we describe as North Pilistreet), running

TABLE 9

Spot-distributions of an intermediate type in the flood-plain, about I6o yards ipide, east of the Tamar between the river and its escarpment

\begin{tabular}{|rr|r|r|r|r|r|r|}
\hline & \multicolumn{5}{|c|}{ Spots } & Total \\
\cline { 3 - 7 } & & 0 & 1 & 2 & 3 & 4 & \\
\hline Females . & $\cdot$ & 67 & 36 & 34 & 5 & $\ldots$ & I 42 \\
Malcs & $\cdot$ & $\ldots$ & 2 & 23 & I I & 5 & 41 \\
\hline
\end{tabular}

northwards for about 300 yards along the upper edge of the woods and separated from the last locality by about $5^{\circ}$ yards (see table 7 ).

We had, therefore, explored a transcct running from the edge of the Tamar Valley eastwards to Chillaton, approximately four miles away. The four populations included in it proved to be homogeneous in both sexes (for the females $\left.\chi_{(9)}^{2}\right)=6 \cdot 239$, with $P>0.7$; for the males, $\chi\left({ }_{3}^{2}\right)=0.935$, with $\left.P>0 \cdot 8\right)$.

We had now established that the Cornish and Southern English populations extended respectively west and east from the Tamar, cach being homogeneous. The distinction between the bimodal Cornish and the unimodal English type of female is heavily significant, with $\chi\left({ }_{3}^{2}\right)=\mathrm{I} 8.086$, giving $P<\mathrm{O} \cdot 00 \mathrm{I}$. The males as before, do not discriminate between the two stabilisations $\left(\chi_{\left(_{3}\right.}^{2}\right)=\mathrm{I} \cdot{ }_{1} 82$, with $P$ betwcen 0.7 and 0.5 ).

In addition to the river itself (about i 5 yards broad) and the precipitous woods from which the butterfly is absent, the Inglish population at Pilistrect and the Cornish on the west bank of the Tamar are separated only by the castern flood-plain, here no more than I 50 yards wide, in which the butterfly is established and in which with difficulty we amassed a considerable sample (see table 9). This proved to be significantly intcrmediate in type, with ncarly equal values at one and two spots in the female. In that sex, the differences involved 
are measured as follows : when compared with the Cornish form, from Lewannick to the west bank of the Tamar, $\chi_{(3)}^{2}=8 \cdot 022$ (with $P=0.05$ $0 \cdot 02$ ), while compared with the Southern English form, from Chillaton to North Pilistreet, $\chi_{(3)}^{2}=10.663$ (with $P<0.02$ ).

We attempted two further collections in what might be intermediate areas. One of these (A, see table Io) consisted of two contiguous fields, carved out of the hanging woods which here isolate the eastern flood-plain from the Pilistreet locality. At the bottom, one of them is separated only by a line of trees from the plain itself. We could only obtain a few butterflies here. These were probably of the intermediate type, but the numbers are too small to be decisive. The other sample (B, see table Io) was caught in a steeply sloping field running south

TABLE Io

(See text)

\begin{tabular}{|c|c|c|c|c|c|c|c|}
\hline \multirow{2}{*}{ Localities } & & \multicolumn{5}{|c|}{ Spots } & \multirow{2}{*}{ Total } \\
\hline & & o & I & 2 & 3 & 4 & \\
\hline $\begin{array}{c}\text { A (males) } \\
\text { (females) }\end{array}$ & & $\begin{array}{r}\cdots \\
3\end{array}$ & $\begin{array}{c}\cdots \\
5\end{array}$ & $\begin{array}{l}5 \\
4\end{array}$ & $\begin{array}{l}4 \\
\mathrm{I}\end{array}$ & $\begin{array}{l}\cdots \\
\cdots\end{array}$ & $\begin{array}{r}9 \\
\text { I } 3\end{array}$ \\
\hline $\mathrm{B}$ (males) & & $\begin{array}{l}\ldots \\
14\end{array}$ & $\begin{array}{l}3 \\
8\end{array}$ & $\begin{array}{r}\text { 1 } 4 \\
5\end{array}$ & $\begin{array}{r}1 \text { I } \\
2\end{array}$ & $\begin{array}{r}\text { I } \\
\ldots\end{array}$ & $\begin{array}{l}29 \\
29\end{array}$ \\
\hline
\end{tabular}

along the top of the woods from the Pilistreet area. Its spot-distribution appears to be typical Southern English, as is to be expected here, but the numbers seem hardly large enough to warrant inclusion in the general calculations.

When a comparison is made of the average spot-numbers for the samples along the transect, in a similar manner to that for the 1956 . results (p. 376), an effect representing the reverse of a cline is again obtained in the females (see fig. 5). However, this time the divergence from the normal is confined to the English side of the boundary (the Pilistreet, though not the North Pilistreet sample). It should be pointed out that, owing to the higher mode at o spots, the average spot-numbers. of the East Cornish samples are rather lower than in 1956 .

In the males the condition in 1957 differs not only from that in the females but also from that in the males the previous year. In 1956 . their spot-averages did not vary at the boundary. In 1957 (see fig. 5) the male samples from the English population at Pilistreet and from the intermediate one at Tamar East, have higher spot-averages. than the other English or East Cornish samples, whereas the females from Pilistreet have a considerably lower spot-average than is obtained either to the east or west.

Powerful selection-pressures are no doubt operating universally 
on Maniola jurtina. The reverse cline effect observed at the junction between the East Cornish and Southern English stabilisations in both r $95^{6}$ and 1957 suggests that here they are of quite exceptional force.

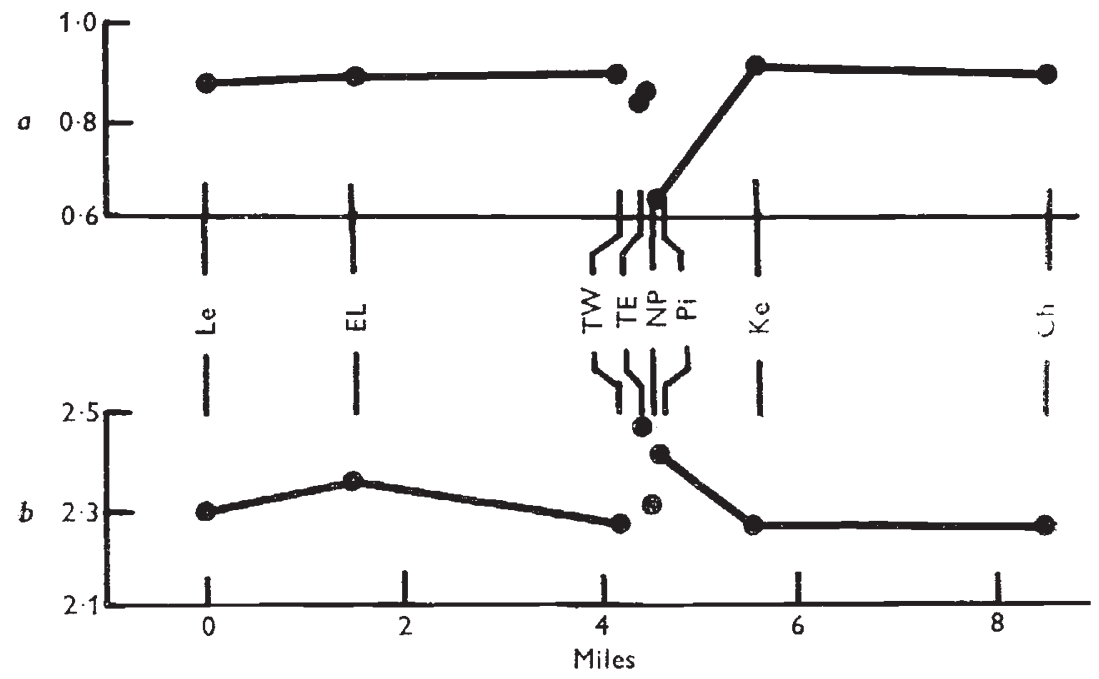

Fig. 5.-Maniola jurtina : the boundary bctween the East Cornish and Southern English stabilisations-1957. The average spot-numbers of $(a)$ the females and $(b)$ the males are plotted against the distance along the transect. For explanation see text pages 376 and $38 \mathrm{r}$. (Le, Lewannick; EL, East Larrick; TW, Tamar West ; TE. Tamar East ; NP, North Pilistrect ; Pi, Pilistreet ; Kc, Kelly ; Ch, Chillaton.)

\section{DISCUSSION}

The most striking of the facts communicated above is the sudden change from the South English (N.E.) to the East Cornish (E.C.) stabilisation (pp. 37 I-82). Beforc we undertook the task of transecting the boundary between these two stabilisation areas we thought we might find, in the following order of likelihoods, (i) a steep cline, or (ii) isolation, i.e. a region in which $M$. jurtina was rare or absent, or (iii) a confused pattern, in which populations with various or intermediate spot-frequencies could be found. It was, therefore, very surprising to find firstly, that the change occurred abruptly at a point where there was no barrier to $M$. jurtina and wherc the population was as dense as it was anywhere else on the transect, and sccondly, that in the immediate neighbourhood of the boundary the female spot-distributions on cach side actually diverged from one another, producing the effect which we describe as the precise opposite of a cline (p. 376).

Our findings in 1956 could be interpreted in two ways : (a) that the two populations were genctically isolated, or $(b)$ that different norms of selection, acting on a genetically continuous population, were in force on either side of the boundary and that the geographic transition from one norm to the other was sharp. The discovery in 
I 957 that the clear-cut boundary between the two stabilisation areas had shifted some three miles eastward forced us to reject explanation (a) above and to accept (b). Clearly, in view of the life-history of $M$. jurtina no population could spread and replace another as rapidly and extensively as would be indicated by a shift of three miles per annum along this transect. Thus we visualise the South English-east Cornish boundary as one at which there is a change-over, not between genetically isolated populations, but between one set of selectional forces and another.

Turning to the data obtained in the former South English stabilisation area, the same kind of explanation offers itself irresistibly. We cannot easily imagine any process of population-replacement causing the change from O.E. to N.E. or P.C. spot-distributions, especially when two of these occur consecutively during the emergence at one locality. It is clear that populations of M.jurtina are subject to powerful, yet buffered, selection-pressures which are occasionally liable to change.

We have no hesitation in postulating strong selection-pressures. Let us consider two closely studied polymorphisms: Allison (r 954) finds that the fitness of sickle-cell heterozygotes in Man is I.26 times that of the normal homozygote in regions of East Africa where malaria is hyperendemic ; Kettlewell ( $195^{8}$ ), discussing the spread of melanism in Biston betularia (L.) since the Industrial Revolution, postulates selective advantages in favour of the carbonaria gene rising to around 30 per cent. The spot-phenotypes of $M$. jurtina seem likely to be controlled by a polygenic system, but strong selection can, of course, still operate on characters governed simultaneously by several genes.

It is tempting to try to identify the selectional forces involved, in the case of $M$. jurtina, although these are immaterial to our thesis if it is admitted that spot-phenotypes are entirely or mainly genetically determined. Conclusive proof can only be obtained from individual breeding experiments, which, despite the great technical difficulties of controlled mating in the Satyride, we hope to perform. Existing data on a population basis, however, indicate that tendencies towards high or low spotting can be inherited from one year to another and we shall present a separate analysis dealing with this point.

In the Isles of Scilly we have noticed some degree of correlation between high spot-values and relative luxuriance of the habitat (McWhirter, 1957) and it was an obvious approach to an explanation of the sudden outbreak of high-spotting all over Southern England to cxamine whether this could be explained by the decimation of the rabbit population after the rapid spread of the virus disease, myxomatosis ; in many areas this produced a lush growth of grasses, including those which are food-plants of $M$. jurtina. Such an hypothesis, however, can hardly be maintained. It is known that rabbits have been absent from Oxford, Medley Manor, since 1947, when they were destroyed by high floods; they had had no opportunity to recover before myxomatosis appeared. Yet the $M$. jurtina population in the vicinity 
has conformed to the general pattern (1956, P.C. ; 1957, P.C. then O.E.).

There are thrce types of discontinuity of spot-distributions discussed in this paper; local (cspccially in the rcgion of the extraordinarily sharp boundary between the South English and East Cornish stabilisation areas), inter-seasonal and intra-seasonal. All three of these show a kind of "quantum" effect which is reflected in triangular diagrams such as figs. I and 2 above and in fig. 2 in McWhirter (1957), where data from the Isles of Scilly are similarly treated. In all thesc diagrams "clumping" of the entrics is strongly markcd. The true explanation of these effects will, we hope, emerge from further investigations.

\section{SUMMARY}

I. Between I953 and I955 the well-established South English stabilisation area, in which all populations of $M$. jurtina had female spot-distributions with large modes at o spots, broke up.

2. Two new types of distribution have appeared in this area, involving higher levels of spotting in both males and females, and these are defined.

3. The wave of high spotting reached a peak in 1956 and receded in 1957.

4. The inception of a new stabilisation area confined to the southwestern part (Devon, Somerset and Dorset) of the former South English stabilisation area is described.

5. Not only local and inter-seasonal, but also intra-seasonal shifts in spot-distribution are now known in several places.

6. In somc cases high spotting seems to have spread through a population after being at first confined to the early part of the emergence.

7. In $195^{2}$ it had been shown that while female spotting is unimodal at o spots in all areas sampled from the North Sea to west Devon, it is bimodal (with a greater mode at $o$ and a lesser at 2 spots) in cast Cornwall. These two types werc stabilised in spite of great environmental differences within the regions they inhabit and persisted to within twclve miles of one another.

8. They still remained distinct in west Devon and east Cornwall in I956.

9. The country separating them was studied in that year. It was then found that one typc was rcplaced by the other in a few yards, at a single ficld-heclgc which was not a barrier to the insect's movement.

Io. The two populations proved to bc subject to a phenomenon which rcpresents the reverse of a clinc. That is to say, their differences in spotting became accentuated as the boundary between them was closcly approached.

II. This general situation persisted in 1957 when the boundary 
separating the West Devon and East Cornish forms had, in the transect we were studying, moved three miles eastwards, to the river Tamar. It was, however, slightly less sharp since an intermediate population inhabited the eastern flood-plain, here only about I 50 yards wide.

I2. An effect representing the reverse of a cline could again be detected in 1957 , for the characteristics of the West Devon, though this season not of the East Cornish, form were accentuated at the point where the two approached most closely.

I3. It is argued that the most likely explanation of the sharp boundary at the Cornish border and of the sudden large changes in the South English populations is that strong selective forces operate on characters connected with spotting; these forces differ locally and, sometimes, when a stabilisation area passes into a fluid state, they appear to differ temporally.

I4. We have considered, but regard as inconclusive, the evidence that the spread of the virus disease, myxomatosis, which has decimated the rabbit population and encouraged lush growth of grasses in many parts of Southern England, might be responsible for the wave of highspotting which reached a peak in 1956 .

I5. Data from areas round the periphery of the former South English stabilisation area (Lundy Island, Isle of Man, Sutherland and Normandy) are briefly considered.

Acknowledgments.-We should like to express our grateful thanks to the Nuffield Foundation for their financial support of this work. One of us (W. H. D.) has received a grant from "Shell" Research Ltd., and also the loan of a calculating machine. This help is most gratefully acknowledged. We are much indebted to the Hon. Miriam Rothschild, Mr S. Beaufoy, Professor L. A. Harvey and Brigadier E. C. L. Simson for the trouble they have taken in obtaining samples for us; also to Dr J. D. F. Frazer for his kindness in allowing us to use his data obtained in Kent. We are most grateful to the following schools for the collections which they have forwarded to us : Blundell's School, Tiverton; Gresham's School, Holt ; King Edward VI School, Chelmsford ; King William's College, Isle of Man ; Lancing College ; North-East Essex Technical College, Colchester ; Rugby ; St Edmund's School, Canterbury; Sherborne School; Taunton School; Winchester College (particularly Mr A. S. Mitchener). Miss Christine Court of the Department of Human Anatomy, Oxford, kindly prepared figs. 3,4 and 5 .

\section{REFERENCES}

Allison, A. C. 1954. Ann. Hum. Genetics, 19, 39-57.

DOBZHANSKY, TH., AND PAVLOVSKY, O. 1957. Evolution, $I \pi$, 3 I I-3 I9.

DOWDESWELl, W. H., AND FORD, E. B. 1952. Heredity, 6, 99-IO9.

DOWDESWell, W. H., AND FORD, E. 8. 1953. Symposia Soc. Exp. Biol., 7, 254-273.

DOWDESWELl, W. H., FORD, E. B., AND MCWHIRTER, K. G. I957. Heredity, II, 5 I-65.

FORMAN, B., FORD, E. B., AND MCWHIRTER, K. G. Heredity, I3, 353-36 I .

KETTLEWELL, H. B. D. I958. Heredity, I2, 51-72.

MCWHIRTER, K. G. I957. Heredity, II, 359-37 I. 


\section{APPENDIX I}

Spot-distributions of Maniola jurtina, 1956

(The serial numbers in the left-hand column refer to the corresponding entries in fig. I.)

\begin{tabular}{|c|c|c|c|c|c|c|c|c|c|}
\hline \multirow{2}{*}{ Locality } & & \multicolumn{6}{|c|}{ Spots } & \multirow{2}{*}{ Total } & \multirow{2}{*}{$\begin{array}{l}\text { Spot- } \\
\text { av. }\end{array}$} \\
\hline & & o & I & 2 & 3 & 4 & 5 & & \\
\hline I. Canterbury, Kent & $\begin{array}{l}\text { ô } \\
\text { o }\end{array}$ & $\begin{array}{r}4 \\
17\end{array}$ & $\begin{array}{r}5 \\
10\end{array}$ & $\begin{array}{r}45 \\
6\end{array}$ & $\begin{array}{r}2 \mathrm{I} \\
2\end{array}$ & $\begin{array}{l}\ldots \\
\cdots\end{array}$ & $\begin{array}{l}\ldots \\
\cdots\end{array}$ & $\begin{array}{l}75 \\
35\end{array}$ & $\begin{array}{l}2 \cdot 11 \\
0.80\end{array}$ \\
\hline 2. Chillaton, Devon & $\begin{array}{l}0 \\
0 \\
+\end{array}$ & $\dddot{38}$ & $\begin{array}{r}9 \\
18\end{array}$ & $\begin{array}{l}63 \\
\text { r } 3\end{array}$ & $\begin{array}{r}17 \\
6\end{array}$ & $\begin{array}{l}9 \\
3\end{array}$ & $\begin{array}{l}\ldots \\
\cdots\end{array}$ & $\begin{array}{l}9^{8} \\
78\end{array}$ & $\begin{array}{l}2 \cdot 27 \\
0 \cdot 95\end{array}$ \\
\hline 3. Chelmsford, Essex . & $\begin{array}{l}0 \\
\vdots \\
+\end{array}$ & $\begin{array}{l}I \\
7\end{array}$ & $\begin{array}{l}3 \\
8\end{array}$ & $\begin{array}{r}27 \\
5\end{array}$ & $\begin{array}{r}14 \\
3\end{array}$ & $\begin{array}{c}2 \\
\cdots\end{array}$ & $\begin{array}{l}\cdots \\
\cdots\end{array}$ & $\begin{array}{l}47 \\
23\end{array}$ & $\begin{array}{l}2 \cdot 28 \\
1 \cdot 17\end{array}$ \\
\hline 4. Cothill, Berkshire & $\begin{array}{l}0 \\
0 \\
+\end{array}$ & I4 & $\begin{array}{r}5 \\
10\end{array}$ & $\begin{array}{r}38 \\
7\end{array}$ & $\begin{array}{r}21 \\
2\end{array}$ & $\begin{array}{l}2 \\
\mathrm{I}\end{array}$ & $\begin{array}{l}\cdots \\
\cdots\end{array}$ & $\begin{array}{l}66 \\
34\end{array}$ & $\begin{array}{l}2 \cdot 30 \\
1 \cdot 00\end{array}$ \\
\hline $\begin{array}{l}\text { 5. East Larrick, } \\
\text { Cornwall }\end{array}$ & $\begin{array}{l}0 \\
0 \\
+\end{array}$ & $\frac{\ldots}{20}$ & $\begin{array}{r}6 \\
\text { I I }\end{array}$ & $\begin{array}{r}5 \mathrm{I} \\
6\end{array}$ & $\begin{array}{r}22 \\
1\end{array}$ & $\begin{array}{l}3 \\
\ldots\end{array}$ & $\begin{array}{l}\cdots \\
\cdots\end{array}$ & $\begin{array}{l}82 \\
38\end{array}$ & $\begin{array}{l}2 \cdot 27 \\
0.68\end{array}$ \\
\hline 6. Holt, Norfolk & $\begin{array}{l}0 \\
0 \\
0\end{array}$ & $\begin{array}{r}3 \\
27\end{array}$ & $\begin{array}{l}\text { I0 } \\
\text { I9 }\end{array}$ & $\begin{array}{r}105 \\
13\end{array}$ & $\begin{array}{r}4 \mathrm{I} \\
3\end{array}$ & $\begin{array}{l}9 \\
\text { I }\end{array}$ & $\begin{array}{l}\mathrm{I} \\
\ldots\end{array}$ & $\begin{array}{r}169 \\
63\end{array}$ & $\begin{array}{l}2 \cdot 27 \\
0 \cdot 9^{2}\end{array}$ \\
\hline 7. Ipswich, Suffolk & $\begin{array}{l}0 \\
0 \\
\vdots\end{array}$ & $\begin{array}{r}I \\
42\end{array}$ & $\begin{array}{r}2 \\
3^{2}\end{array}$ & $\begin{array}{l}65 \\
23\end{array}$ & $\begin{array}{r}38 \\
7\end{array}$ & $\begin{array}{l}8 \\
I\end{array}$ & $\begin{array}{l}\cdots \\
\cdots\end{array}$ & $\begin{array}{l}\text { II } 4 \\
\text { I05 }\end{array}$ & $\begin{array}{l}2 \cdot 44 \\
0 \cdot 98\end{array}$ \\
\hline 8. Lewannick, Cornwall & $\begin{array}{l}0 \\
0 \\
0\end{array}$ & $\begin{array}{r}2 \\
44\end{array}$ & $\begin{array}{r}8 \\
18\end{array}$ & $\begin{array}{l}5^{8} \\
3^{0}\end{array}$ & $\begin{array}{l}27 \\
10\end{array}$ & $\begin{array}{l}8 \\
2\end{array}$ & $\begin{array}{c}\mathrm{I} \\
\ldots\end{array}$ & $\begin{array}{l}104 \\
104\end{array}$ & $\begin{array}{l}2 \cdot 33 \\
1 \cdot 12\end{array}$ \\
\hline 9. Lydford, Devon & $\begin{array}{l}0 \\
0 \\
+\end{array}$ & $\begin{array}{r}4 \\
50\end{array}$ & $\begin{array}{r}8 \\
27\end{array}$ & $\begin{array}{l}49 \\
20\end{array}$ & $\begin{array}{l}\text { I5 } \\
\text { I I }\end{array}$ & $\begin{array}{c}5 \\
\cdots\end{array}$ & $\begin{array}{l}2 \\
\ldots\end{array}$ & $\begin{array}{r}83 \\
108\end{array}$ & $\begin{array}{l}2 \cdot 18 \\
0 \cdot 93\end{array}$ \\
\hline $\begin{array}{l}\text { Io. Middleton East, } \\
\text { Hampshire }\end{array}$ & $\begin{array}{l}0 \\
o \\
a\end{array}$ & $\begin{array}{r}2 \\
93\end{array}$ & $\begin{array}{r}5 \\
43\end{array}$ & $\begin{array}{l}32 \\
12\end{array}$ & $\begin{array}{r}8 \\
\cdots\end{array}$ & $\begin{array}{l}\cdots \\
\cdots\end{array}$ & $\begin{array}{l}\cdots \\
\cdots\end{array}$ & $\begin{array}{r}47 \\
148\end{array}$ & $\begin{array}{l}I \cdot 9^{8} \\
0 \cdot 45\end{array}$ \\
\hline $\begin{array}{l}\text { I I. Middleton Wcst, } \\
\text { Hampshire }\end{array}$ & $\begin{array}{l}0 \\
0 \\
0\end{array}$ & $\begin{array}{r}4 \\
50\end{array}$ & $\begin{array}{r}9 \\
3^{\circ}\end{array}$ & $\begin{array}{l}79 \\
15\end{array}$ & $\begin{array}{r}18 \\
7\end{array}$ & $\begin{array}{c}7 \\
\cdots\end{array}$ & $\cdots$ & $\begin{array}{l}\text { II } 7 \\
102\end{array}$ & $\begin{array}{l}2 \cdot 13 \\
0 \cdot 79\end{array}$ \\
\hline 12. Newbury, Berkshire. & $\stackrel{0}{0}$ & $\begin{array}{l}\mathrm{I} \\
5\end{array}$ & $\begin{array}{l}1 \\
2\end{array}$ & $\begin{array}{r}12 \\
4\end{array}$ & $\begin{array}{l}7 \\
\cdots\end{array}$ & $\begin{array}{c}2 \\
\ldots\end{array}$ & $\cdots$ & $\begin{array}{l}23 \\
\text { II }\end{array}$ & $\begin{array}{l}2 \cdot 35 \\
0 \cdot 91\end{array}$ \\
\hline $\begin{array}{l}\text { 13. Newton Abbot, } \\
\text { Devon }\end{array}$ & $\begin{array}{l}\text { ô } \\
\text { O⿱ }\end{array}$ & 60 & $\begin{array}{l}14 \\
23\end{array}$ & $\begin{array}{r}59 \\
15\end{array}$ & $\begin{array}{r}23 \\
2\end{array}$ & $\begin{array}{l}6 \\
\mathrm{I}\end{array}$ & $\begin{array}{l}\cdots \\
\cdots\end{array}$ & $\begin{array}{l}106 \\
101\end{array}$ & $\begin{array}{l}2 \cdot 12 \\
0.62\end{array}$ \\
\hline I4. Noss Mayo, Devon. & $\begin{array}{l}\text { ô } \\
0 \\
0\end{array}$ & $\begin{array}{r}2 \\
31\end{array}$ & $\begin{array}{r}8 \\
21\end{array}$ & $\begin{array}{l}87 \\
\text { I } 2\end{array}$ & $\begin{array}{r}37 \\
1\end{array}$ & $\begin{array}{l}8 \\
I\end{array}$ & $\begin{array}{l}3 \\
\ldots\end{array}$ & $\begin{array}{r}145 \\
66\end{array}$ & $\begin{array}{l}2 \cdot 34 \\
0 \cdot 79\end{array}$ \\
\hline
\end{tabular}


APPENDIX I-continued

Spot-distributions of Maniola jurtina, 1956

\begin{tabular}{|c|c|c|c|c|c|c|c|c|c|}
\hline \multirow{2}{*}{ Locality } & & \multicolumn{6}{|c|}{ Spots } & \multirow{2}{*}{ Total } & \multirow{2}{*}{$\begin{array}{l}\text { Spot } \\
\text { av. }\end{array}$} \\
\hline & & o & I & 2 & 3 & 4 & 5 & & \\
\hline I5. Okehampton, Devon & o & $\begin{array}{r}\text { I } \\
45\end{array}$ & $\begin{array}{r}8 \\
29\end{array}$ & $\begin{array}{l}55 \\
20\end{array}$ & $\begin{array}{r}\text { I } 8 \\
5\end{array}$ & $\begin{array}{l}\text { I } \\
\cdots\end{array}$ & $\begin{array}{l}\cdots \\
\cdots\end{array}$ & $\begin{array}{l}83 \\
99\end{array}$ & $\begin{array}{l}2 \cdot 12 \\
0.85\end{array}$ \\
\hline $\begin{array}{l}\text { 16. Oxford, Medley } \\
\text { Manor }\end{array}$ & $\begin{array}{l}0 \\
0 \\
+\end{array}$ & $\begin{array}{r}\text { I } \\
44\end{array}$ & $\begin{array}{l}30 \\
22\end{array}$ & $\begin{array}{r}120 \\
29\end{array}$ & $\begin{array}{r}69 \\
8\end{array}$ & $\begin{array}{r}30 \\
2\end{array}$ & $\begin{array}{r}2 \\
\cdots\end{array}$ & $\begin{array}{l}252 \\
105\end{array}$ & $\begin{array}{l}2 \cdot 4 \mathrm{I} \\
\mathrm{I} \cdot 07\end{array}$ \\
\hline I 7. Oxford, Parks & $\begin{array}{l}x \\
0 \\
+\end{array}$ & $\begin{array}{l}\text { I } \\
5\end{array}$ & $\begin{array}{l}7 \\
5\end{array}$ & $\begin{array}{r}3 \mathrm{I} \\
3\end{array}$ & $\begin{array}{l}\text { I3 } \\
\cdots\end{array}$ & $\begin{array}{r}8 \\
\cdots\end{array}$ & $\begin{array}{l}\cdots \\
\cdots\end{array}$ & $\begin{array}{l}60 \\
\text { I } 3\end{array}$ & $\begin{array}{l}2.33 \\
0.85\end{array}$ \\
\hline $\begin{array}{l}\text { I8. Plymouth, Ro- } \\
\text { borough, Devon }\end{array}$ & $\begin{array}{l}0 \\
\text { o } \\
+\end{array}$ & $\begin{array}{r}2 \\
20\end{array}$ & $\begin{array}{l}2 \\
\mathrm{I}\end{array}$ & $\begin{array}{r}10 \\
6\end{array}$ & $\begin{array}{l}7 \\
5\end{array}$ & $\begin{array}{l}\cdots \\
\cdots\end{array}$ & $\begin{array}{l}\cdots \\
\cdots\end{array}$ & $\begin{array}{l}2 \mathrm{I} \\
32\end{array}$ & $\begin{array}{l}2 \cdot 05 \\
0 \cdot 88\end{array}$ \\
\hline 19. Rugby, Warwick- & $\begin{array}{l}0 \\
0 \\
q\end{array}$ & $\begin{array}{r}3 \\
27\end{array}$ & $\begin{array}{l}19 \\
23\end{array}$ & $\begin{array}{l}70 \\
14\end{array}$ & $\begin{array}{r}30 \\
8\end{array}$ & $\begin{array}{l}2 \\
2\end{array}$ & $\begin{array}{r}2 \\
\cdots\end{array}$ & $\begin{array}{r}\text { I } 26 \\
74\end{array}$ & $\begin{array}{l}2 \cdot 12 \\
1 \cdot 12\end{array}$ \\
\hline 20. Shapwick, Somerset & $\begin{array}{l}0 \\
0 \\
0\end{array}$ & $\begin{array}{r}\mathrm{I} \\
\mathrm{I} 8\end{array}$ & $\begin{array}{r}2 \\
\text { I I }\end{array}$ & $\begin{array}{r}35 \\
9\end{array}$ & $\begin{array}{r}12 \\
\text { I }\end{array}$ & $\begin{array}{c}3 \\
\cdots\end{array}$ & $\begin{array}{l}\cdots \\
\cdots\end{array}$ & $\begin{array}{l}53 \\
39\end{array}$ & $\begin{array}{l}2 \cdot 26 \\
0 \cdot 82\end{array}$ \\
\hline 21. Sherborne, Dorset . & $\begin{array}{l}0 \\
0 \\
0\end{array}$ & $\begin{array}{r}5 \\
28\end{array}$ & $\begin{array}{l}\text { I I } \\
\text { IO }\end{array}$ & $\begin{array}{r}82 \\
7\end{array}$ & $\begin{array}{r}29 \\
3\end{array}$ & $\begin{array}{l}5 \\
\cdots\end{array}$ & $\cdots$ & $\begin{array}{r}132 \\
48\end{array}$ & $\begin{array}{l}2 \cdot 14 \\
0 \cdot 69\end{array}$ \\
\hline 22. Shoreham, Sussex & $\begin{array}{l}0 \\
\text { o } \\
+\end{array}$ & $\begin{array}{l}\cdots \\
2 \mathrm{I}\end{array}$ & $\begin{array}{r}8 \\
14\end{array}$ & $\begin{array}{r}60 \\
6\end{array}$ & $\begin{array}{r}\text { I } 7 \\
\text { I }\end{array}$ & $\begin{array}{l}\text { I } \\
\text { I }\end{array}$ & $\begin{array}{l}\cdots \\
\cdots\end{array}$ & $\begin{array}{l}86 \\
43\end{array}$ & $\begin{array}{l}2 \cdot 13 \\
0.77\end{array}$ \\
\hline 23. Taunton, Somerset & $\begin{array}{l}0 \\
0 \\
0\end{array}$ & $\begin{array}{l}\cdots \\
12\end{array}$ & $\begin{array}{l}2 \\
3\end{array}$ & $\begin{array}{r}30 \\
5\end{array}$ & $\begin{array}{r}\text { I9 } \\
\text { I }\end{array}$ & $\begin{array}{c}3 \\
\cdots\end{array}$ & $\begin{array}{l}\cdots \\
\cdots\end{array}$ & $\begin{array}{l}54 \\
2 \mathrm{I}\end{array}$ & $\begin{array}{l}2 \cdot 43 \\
0 \cdot 76\end{array}$ \\
\hline $\begin{array}{l}\text { 24. Tamar West, } \\
\text { Cornwall }\end{array}$ & $\begin{array}{l}0 \\
0 \\
0\end{array}$ & $\begin{array}{r}3 \\
30\end{array}$ & $\begin{array}{r}7 \\
19\end{array}$ & $\begin{array}{r}59 \\
9\end{array}$ & $\begin{array}{r}20 \\
5\end{array}$ & $\begin{array}{l}2 \\
I\end{array}$ & $\ddot{I}$ & $\begin{array}{l}9 \mathrm{I} \\
6_{5}\end{array}$ & $\begin{array}{l}2 \cdot 12 \\
0 \cdot 94\end{array}$ \\
\hline 25. Tiverton, Devon & $\begin{array}{l}0 \\
0 \\
+\end{array}$ & $\ddot{47}$ & $\begin{array}{r}7 \\
18\end{array}$ & $\begin{array}{l}57 \\
23\end{array}$ & $\begin{array}{r}38 \\
8\end{array}$ & $\begin{array}{l}6 \\
\mathrm{I}\end{array}$ & $\begin{array}{l}\cdots \\
\cdots\end{array}$ & $\begin{array}{r}108 \\
97\end{array}$ & $\begin{array}{l}2 \cdot 40 \\
0 \cdot 95\end{array}$ \\
\hline $\begin{array}{l}\text { 26. West Larrick, } \\
\text { Cornwall }\end{array}$ & $\begin{array}{l}0 \\
0 \\
0\end{array}$ & I 6 & $\begin{array}{l}6 \\
6\end{array}$ & $\begin{array}{l}35 \\
\text { I3 }\end{array}$ & $\begin{array}{r}10 \\
5\end{array}$ & $\begin{array}{l}6 \\
\text { I. }\end{array}$ & I & $\begin{array}{l}59 \\
4^{I}\end{array}$ & $\begin{array}{l}2 \cdot 29 \\
1 \cdot 24\end{array}$ \\
\hline $\begin{array}{l}\text { 27. Woolbury Ring, } \\
\text { Hampshire }\end{array}$ & $\begin{array}{l}0 \\
0 \\
0\end{array}$ & $\ddot{3}$ & $\begin{array}{r}3 \\
18\end{array}$ & $\begin{array}{r}42 \\
8\end{array}$ & $\begin{array}{r}13 \\
3\end{array}$ & $\begin{array}{l}3 \\
\mathrm{I}\end{array}$ & $\begin{array}{l}\cdots \\
\cdots\end{array}$ & $\begin{array}{l}6 \mathrm{I} \\
68\end{array}$ & $\begin{array}{l}2 \cdot 26 \\
0 \cdot 69\end{array}$ \\
\hline $\begin{array}{l}\text { 28. Worthy Down, } \\
\text { Hampshire }\end{array}$ & $\begin{array}{l}0 \\
q \\
q\end{array}$ & $60^{2}$ & $\begin{array}{r}7 \\
40\end{array}$ & $\begin{array}{l}73 \\
\text { I } 7\end{array}$ & $\begin{array}{r}35 \\
3\end{array}$ & $\begin{array}{l}2 \\
1\end{array}$ & $\begin{array}{r}\text { I } \\
\ldots\end{array}$ & $\begin{array}{l}\mathrm{I} 2 \mathrm{O} \\
\mathrm{I} 2 \mathrm{I}\end{array}$ & $\begin{array}{l}2 \cdot 26 \\
0 \cdot 72\end{array}$ \\
\hline
\end{tabular}


APPENDIX 2

Spot-distributions of Maniola jurtina, 1957

(The serial numbers in the left-hand column refer to the corresponding entries in fig. 2.)

\begin{tabular}{|c|c|c|c|c|c|c|c|c|c|}
\hline \multirow{2}{*}{ Locality } & & \multicolumn{6}{|c|}{ Spots } & \multirow{2}{*}{ Total } & \multirow{2}{*}{$\begin{array}{l}\text { Spot- } \\
\text { av. }\end{array}$} \\
\hline & & 0 & I & 2 & 3 & 4 & 5 & & \\
\hline $\begin{array}{l}\text { *29. Birdlip, Gloucester- } \\
\text { shire (to 21/vii) }\end{array}$ & $\begin{array}{l}0 \\
\text { o } \\
+\end{array}$ & 6 & $\begin{array}{l}4 \\
6\end{array}$ & $\begin{array}{r}25 \\
3\end{array}$ & $\begin{array}{c}8 \\
\ldots\end{array}$ & $\begin{array}{c}5 \\
\ldots\end{array}$ & $\begin{array}{l}\cdots \\
\cdots\end{array}$ & $\begin{array}{l}42 \\
15\end{array}$ & $\begin{array}{l}2 \cdot 33 \\
0.80\end{array}$ \\
\hline $\begin{array}{l}\text { 30. Birdlip, Gloucester- } \\
\text { shire (28/vii) }\end{array}$ & $\begin{array}{l}0 \\
+\end{array}$ & $\begin{array}{l}\ldots \\
29\end{array}$ & $\begin{array}{c}\ldots \\
9\end{array}$ & $\begin{array}{l}7 \\
6\end{array}$ & $\begin{array}{l}\text { I } \\
\text { I }\end{array}$ & $\begin{array}{l}\mathrm{I} \\
\ldots\end{array}$ & $\cdots$ & $\begin{array}{r}9 \\
45\end{array}$ & $\begin{array}{l}2 \cdot 33 \\
0 \cdot 53\end{array}$ \\
\hline 3. Canterbury, Kent . & $\begin{array}{l}0 \\
+ \\
q\end{array}$ & $\begin{array}{l}\ldots \\
12\end{array}$ & $\begin{array}{l}\text { I } \\
4\end{array}$ & $\begin{array}{r}23 \\
4\end{array}$ & $\begin{array}{c}3 \\
\ldots\end{array}$ & $\begin{array}{l}\cdots \\
\cdots\end{array}$ & $\cdots$ & $\begin{array}{l}27 \\
20\end{array}$ & $\begin{array}{l}2 \cdot 07 \\
0 \cdot 60\end{array}$ \\
\hline 32. Chillaton, Devon - & $\begin{array}{l}0 \\
+ \\
+\end{array}$ & $\begin{array}{l}\ldots \\
27\end{array}$ & $\begin{array}{r}8 \\
19\end{array}$ & $\begin{array}{l}42 \\
10\end{array}$ & $\begin{array}{r}15 \\
5\end{array}$ & $\begin{array}{c}4 \\
\ldots\end{array}$ & $\begin{aligned} & \\
\ldots & \end{aligned}$ & $\begin{array}{l}70 \\
6 \mathrm{I}\end{array}$ & $\begin{array}{l}2 \cdot 26 \\
0 \cdot 89\end{array}$ \\
\hline $\begin{array}{l}\text { 33. East Larrick, } \\
\text { Cornwall }\end{array}$ & $\begin{array}{l}0 \\
0 \\
Q\end{array}$ & $\begin{array}{r}1 \\
27\end{array}$ & $\begin{array}{l}2 \\
3\end{array}$ & $\begin{array}{r}17 \\
9\end{array}$ & $\begin{array}{l}7 \\
5\end{array}$ & $\begin{array}{l}4 \\
\mathrm{I}\end{array}$ & $\begin{array}{l}\cdots \\
\cdots\end{array}$ & $\begin{array}{l}3 \mathrm{I} \\
45\end{array}$ & $\begin{array}{l}2 \cdot 35 \\
0.89\end{array}$ \\
\hline 34. Heswall, Cheshire . & $\begin{array}{l}0 \\
+ \\
q\end{array}$ & $\begin{array}{r}3 \\
28\end{array}$ & $\begin{array}{l}12 \\
\text { IO }\end{array}$ & $\begin{array}{r}47 \\
7\end{array}$ & $\begin{array}{r}10 \\
2\end{array}$ & $\begin{array}{c}4 \\
\cdots\end{array}$ & $\cdots$ & $\begin{array}{l}76 \\
47\end{array}$ & $\begin{array}{l}2.00 \\
0.64\end{array}$ \\
\hline 35. Hoylake, Cheshire & 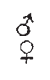 & $\begin{array}{r}2 \\
20\end{array}$ & $\begin{array}{l}5 \\
3\end{array}$ & $\begin{array}{r}22 \\
5\end{array}$ & $\begin{array}{c}4 \\
\cdots\end{array}$ & $\begin{array}{r}\mathrm{I} \\
\cdots\end{array}$ & $\begin{array}{l}\cdots \\
\cdots\end{array}$ & $\begin{array}{l}34 \\
28\end{array}$ & $\begin{array}{l}I \cdot 9 I \\
0 \cdot 46\end{array}$ \\
\hline 36. Holt, Norfolk & $\begin{array}{l}0 \\
0 \\
+\end{array}$ & $\begin{array}{r}4 \\
66\end{array}$ & $\begin{array}{l}12 \\
21\end{array}$ & $\begin{array}{r}128 \\
8\end{array}$ & $\begin{array}{r}39 \\
\mathbf{I}\end{array}$ & $\begin{array}{c}9 \\
\cdots\end{array}$ & $\stackrel{\cdots}{I}$ & $\begin{array}{r}192 \\
96\end{array}$ & $\begin{array}{l}2 \cdot 19 \\
0 \cdot 47\end{array}$ \\
\hline $\begin{array}{l}\text { 37. Intermediate " } \mathrm{A} " \text {, } \\
\text { Devon, }\left(\text { p. } 3^{8 \mathrm{I}}\right)\end{array}$ & $\begin{array}{l}0 \\
0 \\
0\end{array}$ & $\begin{array}{r}\cdots \\
3\end{array}$ & $\begin{array}{r}\cdots \\
5\end{array}$ & $\begin{array}{l}5 \\
4\end{array}$ & $\begin{array}{l}4 \\
\mathrm{I}\end{array}$ & $\begin{array}{l}\ldots \\
\cdots\end{array}$ & $\ldots$ & $\begin{array}{r}9 \\
13\end{array}$ & $\begin{array}{l}2 \cdot 44 \\
1 \cdot 23\end{array}$ \\
\hline $\begin{array}{c}\text { 38. Intermediate " } \mathrm{B} ", \\
\text { Devon }\left(\mathrm{p} \cdot 3^{8 \mathrm{I}}\right)\end{array}$ & $\begin{array}{l}0 \\
0 \\
0 \\
+\end{array}$ & $\begin{array}{l}\ldots \\
14\end{array}$ & $\begin{array}{l}3 \\
8\end{array}$ & $\begin{array}{r}14 \\
5\end{array}$ & $\begin{array}{r}11 \\
2\end{array}$ & $\begin{array}{r}\mathbf{1} \\
\ldots\end{array}$ & $\ldots$ & $\begin{array}{l}29 \\
29\end{array}$ & $\begin{array}{l}2.34 \\
0.83\end{array}$ \\
\hline$\underset{\text { (to 6/vii) }}{* \text { 39. Ipswich, Suffolk }}$ & $\begin{array}{l}0 \\
0 \\
+\end{array}$ & $\begin{array}{l}\text { I } \\
\text { I I }\end{array}$ & $\begin{array}{r}19 \\
8\end{array}$ & $\begin{array}{r}\mathrm{I} 35 \\
4\end{array}$ & $\begin{array}{r}44 \\
3\end{array}$ & $\begin{array}{r}9 \\
\cdots\end{array}$ & $\begin{array}{r}2 \\
\cdots\end{array}$ & $\begin{array}{r}210 \\
26\end{array}$ & $\begin{array}{l}2 \cdot 22 \\
0.96\end{array}$ \\
\hline $\begin{array}{l}\text { 4o. Ipswich, Suffolk } \\
\text { (from 20/vii) }\end{array}$ & ô & $\begin{array}{l}92 \\
9^{1}\end{array}$ & $\begin{array}{l}32 \\
33\end{array}$ & $\begin{array}{l}49 \\
13\end{array}$ & $\begin{array}{r}20 \\
2\end{array}$ & $\begin{array}{l}8 \\
1\end{array}$ & $\begin{array}{r}\mathrm{I} \\
\cdots\end{array}$ & $\begin{array}{r}82 \\
140\end{array}$ & $\begin{array}{l}2 \cdot 40 \\
0 \cdot 49\end{array}$ \\
\hline 41. Kelly, Devon. & $\begin{array}{l}0 \\
+ \\
+\end{array}$ & $\begin{array}{r}\mathrm{I} \\
50\end{array}$ & $\begin{array}{r}5 \\
23\end{array}$ & $\begin{array}{l}22 \\
15\end{array}$ & $\begin{array}{l}\text { II } \\
\text { Io }\end{array}$ & $\begin{array}{l}2 \\
2\end{array}$ & $\begin{array}{r}\mathrm{I} \\
\cdots\end{array}$ & $\begin{array}{r}42 \\
100\end{array}$ & $\begin{array}{l}2 \cdot 26 \\
0 \cdot 91\end{array}$ \\
\hline $\begin{array}{l}\text { 42. Lewannick, } \\
\text { Cornwall }\end{array}$ & $\begin{array}{l}0 \\
0 \\
+\end{array}$ & $\begin{array}{r}2 \\
80\end{array}$ & $\begin{array}{r}7 \\
23\end{array}$ & $\begin{array}{l}79 \\
43\end{array}$ & $\begin{array}{r}29 \\
8\end{array}$ & $\begin{array}{l}9 \\
\text { I }\end{array}$ & $\begin{array}{l}\ldots \\
\ldots\end{array}$ & $\begin{array}{l}\text { I } 26 \\
\text { I } 55\end{array}$ & $\begin{array}{l}2.29 \\
0.88\end{array}$ \\
\hline
\end{tabular}


APPENDIX 2-continued

Spot-distributions of Maniola jurtina, 1957

\begin{tabular}{|c|c|c|c|c|c|c|c|c|c|}
\hline \multirow{2}{*}{ Locality } & & \multicolumn{6}{|c|}{ Spots } & \multirow{2}{*}{ Total } & \multirow{2}{*}{$\begin{array}{l}\text { Spot- } \\
\text { av. }\end{array}$} \\
\hline & & 0 & I & 2 & 3 & 4 & 5 & & \\
\hline $\begin{array}{l}\text { 43. Middleton East, } \\
\text { Hampshire }\end{array}$ & $\begin{array}{l}0 \\
0 \\
+\end{array}$ & $\begin{array}{r}7 \\
\mathrm{I} 26\end{array}$ & $\begin{array}{l}25 \\
41\end{array}$ & $\begin{array}{r}164 \\
20\end{array}$ & $\begin{array}{r}37 \\
3\end{array}$ & $\begin{array}{r}6 \\
\cdots\end{array}$ & $\begin{array}{l}\cdots \\
\cdots\end{array}$ & $\begin{array}{l}239 \\
\text { I } 90\end{array}$ & $\begin{array}{l}2 \cdot 04 \\
0 \cdot 47\end{array}$ \\
\hline $\begin{array}{l}\text { 44. Middleton West, } \\
\text { Hampshire }\end{array}$ & $\begin{array}{l}0 \\
0 \\
+\end{array}$ & $4^{2}$ & $\begin{array}{r}7 \\
16\end{array}$ & $\begin{array}{r}7 \mathrm{I} \\
5\end{array}$ & $\begin{array}{l}16 \\
\cdots\end{array}$ & $\begin{array}{r}8 \\
\cdots\end{array}$ & $\begin{array}{l}\cdots \\
\cdots\end{array}$ & $\begin{array}{r}104 \\
69\end{array}$ & $\begin{array}{l}2 \cdot 20 \\
0 \cdot 38\end{array}$ \\
\hline 45. Newbury, Berkshire. & $\begin{array}{l}0 \\
0 \\
+\end{array}$ & $\ddot{2}$ & $\begin{array}{l}7 \\
8\end{array}$ & $\begin{array}{l}50 \\
17\end{array}$ & $\begin{array}{r}23 \\
1\end{array}$ & $\begin{array}{c}9 \\
\cdots\end{array}$ & $\begin{array}{r}\text { I } \\
\cdots\end{array}$ & $\begin{array}{l}90 \\
5^{1}\end{array}$ & $\begin{array}{l}2.41 \\
0.88\end{array}$ \\
\hline $\begin{array}{l}\text { 46. North Pilistreet, } \\
\text { Devon }\end{array}$ & $\begin{array}{l}0 \\
0 \\
+\end{array}$ & $\dddot{26}$ & $\begin{aligned} 3 \\
\text { I I }\end{aligned}$ & $\begin{array}{r}25 \\
8\end{array}$ & $\begin{array}{l}9 \\
4\end{array}$ & $\begin{array}{l}3 \\
\text { I }\end{array}$ & $\begin{array}{l}\cdots \\
\cdots\end{array}$ & $\begin{array}{l}40 \\
50\end{array}$ & $\begin{array}{l}2 \cdot 30 \\
0 \cdot 36\end{array}$ \\
\hline $\begin{array}{l}\text { 47. Newton Abbot, } \\
\text { Devon }\end{array}$ & $\begin{array}{l}0 \\
0 \\
q\end{array}$ & $\begin{array}{r}\text { I } \\
32\end{array}$ & $\begin{array}{r}3 \\
20\end{array}$ & $\begin{array}{r}24 \\
8\end{array}$ & $\begin{array}{l}6 \\
2\end{array}$ & $\begin{array}{l}\cdots \\
\cdots\end{array}$ & $\begin{array}{l}\cdots \\
\cdots\end{array}$ & $\begin{array}{l}34 \\
62\end{array}$ & $\begin{array}{l}2 \cdot 03 \\
0.68\end{array}$ \\
\hline $\begin{array}{l}{ }^{*} 4 \text {. Oxford, Medley } \\
\text { Manor (to } 5 / \text { vii) }\end{array}$ & $\begin{array}{l}0 \\
0 \\
+\end{array}$ & $\begin{array}{r}4 \\
25\end{array}$ & $\begin{array}{l}23 \\
17\end{array}$ & $\begin{array}{r}\text { I } 27 \\
21\end{array}$ & $\begin{array}{r}17 \\
5\end{array}$ & $\begin{array}{r}4 \\
\cdots\end{array}$ & $\begin{array}{l}\cdots \\
\cdots\end{array}$ & $\begin{array}{r}175 \\
68\end{array}$ & $\begin{array}{l}\text { I. } 97 \\
\text { I.09 }\end{array}$ \\
\hline $\begin{array}{l}\text { 49. Oxford, Medley } \\
\text { Manor (24/vii) }\end{array}$ & $\begin{array}{l}0 \\
\text { o } \\
\text { + }\end{array}$ & I6 & $\begin{array}{l}6 \\
9\end{array}$ & $\begin{array}{r}\mathrm{I} 4 \\
2\end{array}$ & $\begin{array}{l}6 \\
\text { I }\end{array}$ & $\begin{array}{l}\cdots \\
\cdots\end{array}$ & $\begin{array}{r}\text { I } \\
\cdots\end{array}$ & $\begin{array}{l}27 \\
28\end{array}$ & $\begin{array}{l}2 \cdot \text { I I } \\
0 \cdot 57\end{array}$ \\
\hline $\begin{array}{c}*^{*} \text { o. Oxford, Parks } \\
(7 / \text { vii })\end{array}$ & $\begin{array}{l}0 \\
\text { ot } \\
+\end{array}$ & $\begin{array}{r}2 \\
54\end{array}$ & $\begin{array}{l}10 \\
21\end{array}$ & $\begin{array}{l}56 \\
23\end{array}$ & $\begin{array}{r}\text { I6 } \\
6\end{array}$ & $\begin{array}{r}5 \\
\cdots\end{array}$ & $\begin{array}{l}\cdots \\
\cdots\end{array}$ & $\begin{array}{r}89 \\
104\end{array}$ & $\begin{array}{l}2.13 \\
0.82\end{array}$ \\
\hline $\begin{array}{c}\text { 51. Oxford, Parks } \\
(23,29 / \text { vii })\end{array}$ & $\begin{array}{l}\text { đ } \\
0 \\
+\end{array}$ & $\begin{array}{l}\cdots \\
53\end{array}$ & $\begin{array}{r}6 \\
19\end{array}$ & $\begin{array}{l}25 \\
\text { I I }\end{array}$ & $\begin{array}{l}8 \\
\mathrm{I}\end{array}$ & $\begin{aligned} & \\
& \cdots\end{aligned}$ & $\ddot{I}$ & $\begin{array}{l}40 \\
85\end{array}$ & $\begin{array}{l}2 \cdot 10 \\
0.5^{8}\end{array}$ \\
\hline 52. Pilistreet, Devon & $\begin{array}{l}0 \\
0 \\
0\end{array}$ & $\cdots$ & $\dddot{20}$ & $\begin{array}{r}25 \\
8\end{array}$ & $\begin{array}{r}12 \\
6\end{array}$ & $\begin{array}{r}2 \\
\cdots\end{array}$ & $\begin{array}{l}\cdots \\
\cdots\end{array}$ & $\begin{array}{l}39 \\
85\end{array}$ & $\begin{array}{l}2 \cdot 4 \mathrm{I} \\
0.64\end{array}$ \\
\hline 53. Rugby, Warwickshire & $\begin{array}{l}0 \\
0 \\
+9\end{array}$ & $\begin{array}{l}\text { I } \\
\text { I I }\end{array}$ & $\begin{array}{l}\text { I } \\
2\end{array}$ & $\begin{array}{r}16 \\
2\end{array}$ & $\begin{array}{r}4 \\
\ldots\end{array}$ & $\begin{array}{l}\ldots \\
\cdots\end{array}$ & $\begin{array}{l}\ldots \\
\cdots\end{array}$ & $\begin{array}{l}22 \\
15\end{array}$ & $\begin{array}{l}2 \cdot 05 \\
0 \cdot 40\end{array}$ \\
\hline 54. Sherborne, Dorset & $\begin{array}{l}0 \\
0 \\
0\end{array}$ & 2I & $\begin{array}{r}6 \\
11\end{array}$ & $\begin{array}{r}57 \\
7\end{array}$ & $\begin{array}{r}12 \\
\mathrm{I}\end{array}$ & $\begin{array}{r}2 \\
\cdots\end{array}$ & $\begin{array}{l}\cdots \\
\cdots\end{array}$ & $\begin{array}{l}77 \\
40\end{array}$ & $\begin{array}{l}2 \cdot 13 \\
0.70\end{array}$ \\
\hline 55. Taunton, Somerset . & $\begin{array}{l}0 \\
0 \\
0\end{array}$ & $\begin{array}{r}2 \\
\text { I } 5\end{array}$ & $\begin{array}{r}7 \\
\text { I I }\end{array}$ & $\begin{array}{r}75 \\
9\end{array}$ & $\begin{array}{r}20 \\
3\end{array}$ & $\begin{array}{r}2 \\
\cdots\end{array}$ & $\begin{array}{l}\cdots \\
\cdots\end{array}$ & $\begin{array}{r}106 \\
3^{8}\end{array}$ & $\begin{array}{l}2 \cdot 12 \\
1 \cdot 00\end{array}$ \\
\hline 56. Tamar East, Devon & $\begin{array}{l}0 \\
0 \\
+\end{array}$ & $\dddot{67}$ & $3^{2}$ & $\begin{array}{l}23 \\
34\end{array}$ & $\begin{array}{r}\text { I I } \\
5\end{array}$ & $\begin{array}{r}5 \\
\cdots\end{array}$ & $\begin{array}{l}\cdots \\
\cdots\end{array}$ & $\begin{array}{r}41 \\
142\end{array}$ & $\begin{array}{l}2 \cdot 46 \\
0.84\end{array}$ \\
\hline $\begin{array}{l}\text { 57. Tamar West, } \\
\text { Cornwall }\end{array}$ & $\begin{array}{l}0 \\
0 \\
q\end{array}$ & $8_{4}^{2}$ & $\begin{array}{r}4 \\
3^{2}\end{array}$ & $\begin{array}{l}35 \\
41\end{array}$ & $\begin{array}{r}9 \\
12\end{array}$ & $\begin{array}{r}4 \\
\ldots\end{array}$ & $\begin{array}{r}2 \\
\ldots\end{array}$ & $\begin{array}{r}5^{6} \\
169\end{array}$ & $\begin{array}{l}2 \cdot 27 \\
0.89\end{array}$ \\
\hline 58. Tiverton, Devon & $\begin{array}{l}0 \\
\text { ôt } \\
\text { क }\end{array}$ & $\begin{array}{l}\text { I } \\
8\end{array}$ & $\begin{array}{r}3 \\
\text { I I }\end{array}$ & $\begin{array}{r}37 \\
6\end{array}$ & $\begin{array}{r}10 \\
3\end{array}$ & $\begin{array}{c}3 \\
\ldots\end{array}$ & $\begin{array}{l}\text { I } \dagger \\
\cdots\end{array}$ & $\begin{array}{l}55 \\
28\end{array}$ & $\begin{array}{l}2 \cdot 27 \\
1 \cdot 14\end{array}$ \\
\hline $\begin{array}{l}\text { 59. Worthy Down, } \\
\text { Hampshire }\end{array}$ & $\begin{array}{l}0 \\
\stackrel{9}{q}\end{array}$ & $\begin{array}{r}4 \\
73\end{array}$ & $\begin{array}{r}9 \\
27\end{array}$ & $\begin{array}{l}7 \text { I } \\
\text { I I }\end{array}$ & $\begin{array}{r}20 \\
3\end{array}$ & $\begin{array}{r}3 \\
\ldots\end{array}$ & $\begin{array}{l}\ldots \\
\ldots\end{array}$ & $\begin{array}{l}\text { I07 } \\
\text { I I } 4\end{array}$ & $\begin{array}{l}2.08 \\
0.51\end{array}$ \\
\hline
\end{tabular}

* Arbitrary divisions have been made in these sets of data to illustrate the difference between the early and later parts of the emergence. Copies of these data giving complete details of dates of capture have been deposited in the Radcliffe Library, Oxford.

$\dagger$ This specimen had six spots. 


\section{APPENDIX $_{3}$}

Data indicating intra-seasonal homogeneity at two locations in 1957

\begin{tabular}{|c|c|c|c|c|c|c|c|c|c|c|}
\hline \multirow{2}{*}{\multicolumn{2}{|c|}{ Locality }} & & \multicolumn{6}{|c|}{ Spots } & \multirow{2}{*}{ Total } & \multirow{2}{*}{$\begin{array}{l}\text { Spot- } \\
\text { av. }\end{array}$} \\
\hline & & & 0 & $I$ & 2 & 3 & 4 & 5 & & \\
\hline \multicolumn{2}{|c|}{$\begin{array}{l}\text { Middleton East, } \\
\text { Hampshire (18/vi) }\end{array}$} & ๘ & I & 6 & 43 & I I & $\ldots$ & $\ldots$ & $6 \mathrm{I}$ & $2 \cdot 05$ \\
\hline$(30 / v i)$ & . & $\begin{array}{l}0 \\
0 \\
+\end{array}$ & $\begin{array}{l}\text { I } \\
9\end{array}$ & $\begin{array}{l}2 \\
1\end{array}$ & $\begin{array}{l}14 \\
\cdots\end{array}$ & $\begin{array}{l}4 \\
\text { I }\end{array}$ & $\begin{array}{l}\cdots \\
\cdots\end{array}$ & $\begin{array}{l}\cdots \\
\cdots\end{array}$ & $\begin{array}{l}2 \mathrm{I} \\
1 \mathrm{I}\end{array}$ & $\begin{array}{l}2 \cdot 00 \\
0 \cdot 36\end{array}$ \\
\hline$(6 / v i i)$ & . & $\begin{array}{l}0 \\
\vdots \\
+\end{array}$ & $\begin{array}{r}5 \\
2 \mathrm{I}\end{array}$ & $\begin{array}{r}14 \\
7\end{array}$ & $\begin{array}{r}84 \\
6\end{array}$ & $\begin{array}{l}22 \\
\cdots\end{array}$ & $\begin{array}{c}6 \\
\ldots\end{array}$ & $\begin{array}{l}\cdots \\
\cdots\end{array}$ & $\begin{array}{r}\text { I3 } 1 \\
34\end{array}$ & $\begin{array}{l}2 \cdot 08 \\
0.56\end{array}$ \\
\hline$(27 / v i i)$ & & q & $4^{2}$ & 13 & 3 & $\cdots$ & $\ldots$ & $\cdots$ & $5^{8}$ & 0.33 \\
\hline$(\mathrm{I} / \mathrm{ix})$ & . & $\begin{array}{l}0 \\
0 \\
+\end{array}$ & $\begin{array}{l}\ldots \\
3^{2}\end{array}$ & $\begin{array}{r}2 \\
14\end{array}$ & $\begin{array}{r}17 \\
7\end{array}$ & $\ddot{2}$ & $\begin{array}{l}\cdots \\
\cdots\end{array}$ & $\begin{array}{l}\cdots \\
\cdots\end{array}$ & $\begin{array}{l}19 \\
55\end{array}$ & $\begin{array}{l}1 \cdot 89 \\
0 \cdot 62\end{array}$ \\
\hline$(2 / \mathrm{ix})$ & . & $\begin{array}{l}0 \\
0 \\
0 \\
+\end{array}$ & $\begin{array}{ll}\ldots \\
22\end{array}$ & $\begin{array}{l}\text { I } \\
6\end{array}$ & $\begin{array}{l}6 \\
4\end{array}$ & $\begin{array}{l}\cdots \\
\cdots\end{array}$ & $\begin{array}{l}\cdots \\
\cdots\end{array}$ & $\cdots$ & $\begin{array}{r}7 \\
3^{2}\end{array}$ & $\begin{array}{c}\ldots \\
0 * 44\end{array}$ \\
\hline
\end{tabular}

If the females are classed into those at o spots and those at one or more than one spots, and if the samples are grouped into early (3o/vi and 6/vii), middle (27/vii) and late ( $\mathrm{I} / \mathrm{ix}$ and $2 /$ ix) emergences, then $\chi(2)=1.67 ; 0.5>P>0.3$.

\begin{tabular}{|c|c|c|c|c|c|c|c|c|c|}
\hline \multirow{2}{*}{ Locality } & & \multicolumn{6}{|c|}{ Spots } & \multirow{2}{*}{ Total } & \multirow{2}{*}{$\begin{array}{l}\text { Spot- } \\
\text { av. }\end{array}$} \\
\hline & & 0 & I & 2 & 3 & 4 & 5 & & \\
\hline $\begin{array}{l}\text { Middleton West, } \\
\text { Hampshire (18/vi) }\end{array}$ & $\begin{array}{l}0 \\
0 \\
0\end{array}$ & $\begin{array}{l}\text { I } \\
\text { I }\end{array}$ & $\begin{array}{l}5 \\
\text { I }\end{array}$ & $\begin{array}{l}33 \\
\cdots\end{array}$ & $\begin{array}{c}6 \\
\cdots\end{array}$ & $\begin{array}{c}5 \\
\cdots\end{array}$ & $\begin{array}{l}\cdots \\
\cdots\end{array}$ & $\begin{array}{r}50 \\
2\end{array}$ & $\begin{array}{l}2 \cdot 18 \\
\cdots\end{array}$ \\
\hline (6/vii) & $\begin{array}{l}0 \\
\text { o } \\
+\end{array}$ & $\begin{array}{l}\ldots \\
12\end{array}$ & $\begin{array}{l}1 \\
5\end{array}$ & $\begin{array}{r}30 \\
2\end{array}$ & $\begin{array}{c}9 \\
\cdots\end{array}$ & $\begin{array}{l}2 \\
\ldots\end{array}$ & $\cdots$ & $\begin{array}{l}42 \\
19\end{array}$ & $\begin{array}{l}2 \cdot 29 \\
0 \cdot 47\end{array}$ \\
\hline$(27 / v i i)$ & $\begin{array}{l}0 \\
+ \\
+\end{array}$ & $\begin{array}{r}1 \\
15\end{array}$ & $\begin{array}{l}\text { I } \\
6\end{array}$ & $\begin{array}{l}8 \\
2\end{array}$ & $\begin{array}{c}\mathrm{I} \\
\cdots\end{array}$ & $\begin{array}{r}\mathbf{I} \\
\ldots\end{array}$ & $\cdots$ & $\begin{array}{l}12 \\
23\end{array}$ & $\begin{array}{l}2 \cdot 00 \\
0 \cdot 43\end{array}$ \\
\hline (r6/viii) & q & 20 & 4 & I & $\cdots$ & $\cdots$ & $\ldots$ & 25 & 0.24 \\
\hline
\end{tabular}

Classifying the females as above in the case of Middleton East, $\chi \underset{(2)}{2}=2 \cdot 07 ; 0.5>P>0.3$. 
APPENDIX 4

Data indicating intra-seasonal shift from populations at Burham Down, Kent, scored by F. D. F. Frazer

\begin{tabular}{|c|c|c|c|c|c|c|c|c|c|c|}
\hline \multirow{2}{*}{ Locality } & & & \multicolumn{6}{|c|}{ Spots } & \multirow{2}{*}{ Total } & \multirow{2}{*}{$\begin{array}{l}\text { Spot- } \\
\text { av. }\end{array}$} \\
\hline & & & 0 & I & 2 & 3 & 4 & 5 & & \\
\hline $\begin{array}{c}\text { Locality " A ", r } 955 \\
\text { (to } 23 / \text { vii) }\end{array}$ & • & $\begin{array}{l}0 \\
\text { o } \\
0\end{array}$ & $\ddot{18}$ & $\begin{array}{l}3 \\
4\end{array}$ & $\begin{array}{l}5^{8} \\
11\end{array}$ & $\begin{array}{l}6 \\
2\end{array}$ & $\begin{array}{r}3 \\
\cdots\end{array}$ & $\begin{array}{l}\cdots \\
\cdots\end{array}$ & $\begin{array}{l}70 \\
35\end{array}$ & $\begin{array}{l}2 \cdot 13 \\
0 \cdot 91\end{array}$ \\
\hline (after 23/vii) & . & $\begin{array}{l}0 \\
0 \\
0\end{array}$ & $\begin{array}{r}5 \\
208\end{array}$ & $\begin{array}{l}15 \\
36\end{array}$ & $\begin{array}{r}\text { I Io } \\
\text { I } 9\end{array}$ & $\begin{array}{l}5 \\
2\end{array}$ & $\begin{array}{l}\cdots \\
\cdots\end{array}$ & $\begin{array}{r}\text { I } \\
\cdots\end{array}$ & $\begin{array}{l}136 \\
265\end{array}$ & $\begin{array}{l}1 \cdot 88 \\
0 \cdot 30\end{array}$ \\
\hline $\begin{array}{c}\text { Locality "A ", } 1956 \\
\text { (to } 22 / \text { vii) }\end{array}$ & . & $\begin{array}{l}0 \\
0 \\
0\end{array}$ & $\begin{array}{r}4 \\
48\end{array}$ & $\begin{array}{l}36 \\
15\end{array}$ & $\begin{array}{r}308 \\
20\end{array}$ & $\begin{array}{r}92 \\
4\end{array}$ & $\begin{array}{l}18 \\
\cdots\end{array}$ & $\begin{array}{r}3 \\
\cdots\end{array}$ & $\begin{array}{r}461 \\
87\end{array}$ & $\begin{array}{l}2 \cdot 20 \\
0 \cdot 77\end{array}$ \\
\hline (26/vii-2/viii) & . & $\begin{array}{l}0 \\
0 \\
0\end{array}$ & 2I & $\begin{array}{l}6 \\
5\end{array}$ & $\begin{array}{r}69 \\
2\end{array}$ & $\begin{array}{l}\text { I3 } \\
\ldots\end{array}$ & $\begin{array}{r}3 \\
\ldots\end{array}$ & $\begin{array}{r}\text { I } \\
\cdots\end{array}$ & $\begin{array}{l}92 \\
28\end{array}$ & $\begin{array}{l}2 \cdot 17 \\
0 \cdot 32\end{array}$ \\
\hline (after $2 /$ viii) & . & $\begin{array}{l}0 \\
0 \\
0 \\
+\end{array}$ & $\begin{array}{r}4 \\
105\end{array}$ & $\begin{array}{r}7 \\
29\end{array}$ & $\begin{array}{l}82 \\
14\end{array}$ & $\begin{array}{l}1 \\
3\end{array}$ & I & $\begin{array}{l}\cdots \\
\cdots\end{array}$ & $\begin{array}{r}95 \\
152\end{array}$ & $\begin{array}{l}1 \cdot 87 \\
0 \cdot 46\end{array}$ \\
\hline $\begin{array}{l}\text { Locality "A ", } 1957 \\
\text { (to 3o/vi) }\end{array}$ & • & o & $\begin{array}{r}2 \\
27\end{array}$ & $\begin{array}{r}15 \\
6\end{array}$ & $\begin{array}{r}256 \\
15\end{array}$ & $\begin{array}{r}73 \\
5\end{array}$ & $\begin{array}{l}23 \\
\cdots\end{array}$ & $\begin{array}{r}6 \\
\ldots\end{array}$ & $\begin{array}{r}375 \\
53\end{array}$ & $\begin{array}{l}2 \cdot 3 \text { I } \\
0 \cdot 96\end{array}$ \\
\hline ( 7 and $10 / v i i)$ & . & $\begin{array}{l}0 \\
\text { o }\end{array}$ & $\begin{array}{r}I \\
3^{2}\end{array}$ & $\begin{array}{l}8 \\
9\end{array}$ & $\begin{array}{r}83 \\
3\end{array}$ & $\begin{array}{r}20 \\
5\end{array}$ & $\begin{array}{r}8 \\
\ldots\end{array}$ & $\begin{array}{l}\ldots \\
\cdots\end{array}$ & $\begin{array}{r}120 \\
49\end{array}$ & $\begin{array}{l}2 \cdot 22 \\
0.61\end{array}$ \\
\hline
\end{tabular}

Arbitrary divisions have been made in these data to illustrate the differences between the various phases of the emergences. Each phase appears to be quite homogeneous and to be sharply distinguishable from other phases of the same emergence : all these data will be the subject of further, more detailed analysis. Both sexes appear to change simultaneously in 1955 ; in 1956 there is a short period during which the females have changed but not the males ; in 1957 there is no evidence of any change in the males up to July ro.

Copies of these data giving complete details of dates of capture and some further information concerning Locality "B" (two miles from Locality "A"), where no intra-seasonal shift could be detected in 1957, have been deposited in the Radcliffe Library, Oxford. 